\title{
Peach palm (Bactris gasipaes) in tropical Latin America: implications for biodiversity conservation, natural resource management and human nutrition
}

\author{
Sophie Graefe • Dominique Dufour • Maarten van Zonneveld • \\ Fernando Rodriguez • Alonso Gonzalez
}

Received: 12 July 2012/ Accepted: 14 November 2012/Published online: 13 December 2012

(C) The Author(s) 2012. This article is published with open access at Springerlink.com

\begin{abstract}
Peach palm (Bactris gasipaes) is a multi-purpose palm tree native to tropical Latin America, which is predominantly cultivated by smallholders in agroforestry systems. The fruits are rich in starch and contribute importantly to food security and the cash income of farmers who cultivate them. Complex value chains have emerged that link producers to consumers, but irregular product quality and market chain inequalities undermine the economic well-being of producers and retailers. Peach palm is genetically diverse, but screening for traits of commercial and nutritional interest is required to enhance the use of its genetic resources. Alliances between public organizations and private enterprises are needed to realize the potential for processing novel products from peach palm, especially in the pharmaceutical and cosmetic sectors. The diverse challenges that emerge at different stages of production, processing and marketing require participatory research that directly involves stakeholders from the beginning.
\end{abstract}

Keywords Agroforestry - Bactris gasipaes - Genetic diversity · Livelihoods · Nutrition · Processing

S. Graefe · D. Dufour · F. Rodriguez · A. Gonzalez

International Center for Tropical Agriculture (CIAT), Recta Cali-Palmira km 17, Cali, Colombia

Present Address:

S. Graefe $(\bowtie)$

Georg-August-Universität Göttingen, Büsgenweg 1, 37077 Göttingen, Germany

e-mail: sgraefe@gwdg.de

D. Dufour

CIRAD, UMR Qualisud, Recta Cali-Palmira km 17, Cali, Colombia

D. Dufour

CIRAD, UMR Qualisud, Avenue Agropolis, Montpellier, France

M. van Zonneveld

Bioversity International, Regional Office for the Americas, Recta Cali-Palmira km 17, Cali, Colombia

M. van Zonneveld

Faculty of Bioscience Engineering, Ghent University, Coupure links 653, 9000 Gent, Belgium 


\section{Introduction}

Peach palm (Bactris gasipaes) is a multi-purpose palm tree providing starchy edible fruits and palm heart. It may be considered the most important domesticated palm species of the Neotropics. Reports indicate that it was already widely used during pre-Columbian times (Clement and Urpi 1987; (Patiño 2000)). Today Brazil, Colombia, Peru and Costa Rica are the largest producers of peach palm (Clement et al. 2004). Though cultivated mainly by smallholders in agroforestry systems, it may be also found in monocultures. Wild and cultivated peach palm populations are genetically diverse and could offer useful traits for breeding (Araújo et al. 2010). Land use and climate change pose a serious threat to wild populations in situ, and while several large ex situ field collections of mainly cultivated type accessions exist, these are difficult to maintain because of the high costs (Clement et al. 2004). Peach palm fruits provide a nutritious food that contributes importantly both to the food security and cash income of farmers cultivating the tree. In some regions, such as the Colombian Pacific Coast, peach palm has particular significance, and complex value chains have emerged that link producers with consumers.

This review paper highlights scientific knowledge about peach palm fruit production that comes from different technical disciplines and has not been covered in previous reviews-at least not from such a broad perspective (e.g., Mora-Urpí et al. 1997; Clement et al. 2004, 2010; Bernal et al. 2011). The review also identifies aspects that research has so far neglected but have potential to improve the well-being of people involved in peach palm production and marketing. While presenting evidence from all the main cultivation regions of Latin America, this paper gives special emphasis to Colombia, where the International Center of Tropical Agriculture (CIAT) has been involved in peach palm research for several years.

\section{Origin, genetic resources and conservation of peach palm}

Distribution and domestication

Peach palm was commonly cultivated and used in tropical Latin America during preColumbian times; chronicles have recorded more than 300 different indigenous names for the fruit since the European invasion (Patiño 2000). Mapping of georeferenced genebank and herbarium registers obtained from the Global Biodiversity Information Facility (GBIF 2011) and the Brazilian Distributed Information System for Biological Collections (Species Link 2011) have shown that cultivated peach palm is extensively distributed from Honduras southwards to Central Bolivia and eastwards to Para in Brazil (Fig. 1). The widespread cultivation of peach palm in the Americas reflects its capacity to adapt to a wide range of ecological conditions in the tropics and subtropics. It is usually grown on deep, well-drained soils in areas below $800 \mathrm{~m}$ asl, with annual precipitation of 2,000-5,000 $\mathrm{mm}$ and an annual mean temperature above $24{ }^{\circ} \mathrm{C}$ (Mora-Urpí et al. 1997). Peach palm is occasionally found at higher altitudes of up to $1,800 \mathrm{~m}$ asl, as is the case in Colombia's Cauca region (El Tambo).

Peach palm can be subdivided into the cultivated variety, B. gasipaes Kunth var. gasipaes, and the wild form B. gasipaes Kunth var. chichagui (H. Karsten) (Henderson 2000). Phylogenetic studies of chloroplast and nuclear DNA polymorphism in species from the Bactris clade have confirmed a close relationship between cultivated and wild peach palm accessions (Couvreur et al. 2007). Cultivated populations can be divided on the basis 


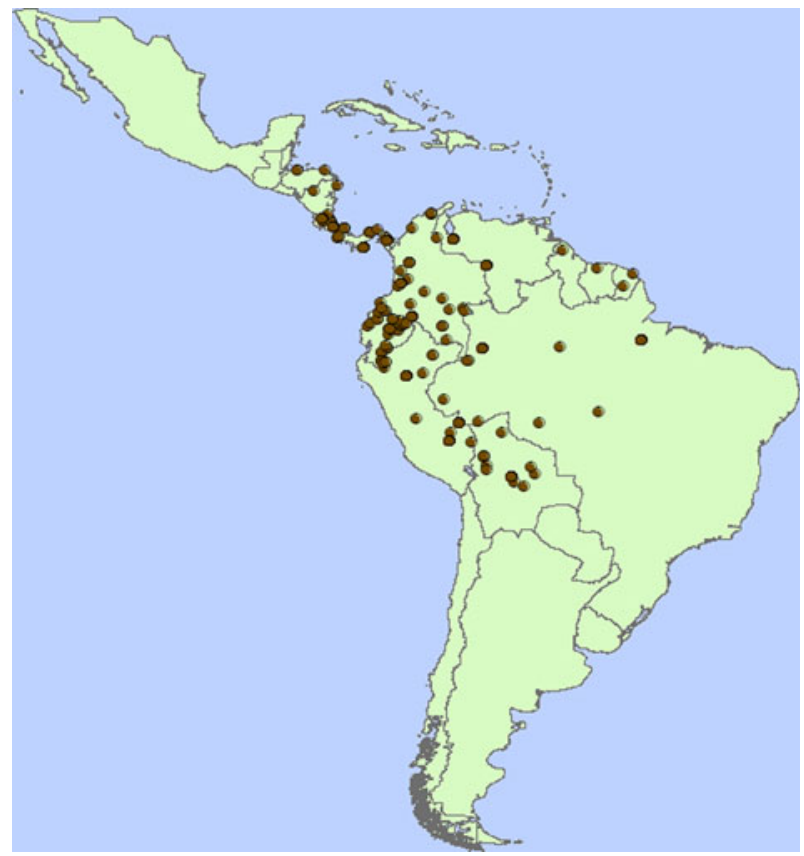

Fig. 1 Peach palm distribution based on herbaria and genebank data

of phenotypic and genetic diversity into (a) two western populations (i. Central America, Colombian inter-Andean valleys and Pacific lowlands in Colombia and Ecuador; ii. interAndean valleys in Venezuela) and (b) two eastern populations (i. upper Amazon and ii. eastern Amazon) (Mora-Urpí et al. 1997; Rodrigues et al. 2004; Hernández-Ugalde et al. 2008). In general, landraces from the western group have harder stems, more abundant and stronger spines, larger leaves and more solid rooting in their juvenile phase (Mora-Urpí et al. 1997). The wild form can be further subdivided into three types based on taxonomical differences: type I of the southern Amazon; type II of northeast Colombia and northwest Venezuela; and type III of the Tropical Andes, southwest Amazon and Central America (Henderson 2000; Clement et al. 2009).

Though the exact origin of cultivated peach palm remains open to debate, three hypotheses have been proposed (Clement et al. 2010): (i) a single domestication event in the southwestern Amazon, as suggested by phylogenetic studies (Ferreira 1999) and RAPD marker-based studies (Rodrigues et al. 2004); (ii) a single domestication event in the Colombian inter-Andean valleys and adjacent Pacific lowlands, as suggested by archeological evidence (Morcote-Rios and Bernal 2001); and (iii) multiple independent centers of domestication (Mora-Urpí 1999; Hernández-Ugalde et al. 2011).

\section{Diversity}

Peach palm is a predominantly outcrossing species, though self-fertilization has also been observed (Mora-Urpí et al. 1997). Pollination is carried out mainly by insects, particularly small curculionid beetles over distances between 100 and $500 \mathrm{~m}$; wind and gravity can also function as pollen vectors (Mora-Urpí et al. 1997; Clement et al. 2009). Since peach palm 
is a long-lived perennial and a predominantly outcrossing species, one can expect its populations and landraces to contain high levels of genetic diversity (Hamrick and Godt 1996; Mora-Urpí et al. 1997). In addition, extensive human dispersal up to a distance of $600 \mathrm{~km}$ has further stimulated gene flow and low differentiation (Cole et al. 2007). A review of studies on genetic variation within and between populations, using different types of markers and considering allelic richness (A), expected heterozigosity (He) and genetic differentiation (Gst), supports those observations (Table 1). Even so, the studies reveal no clear areas of high diversity, and their use of different sampling methods, molecular marker techniques, markers and genetic parameters makes comparison difficult. The use of standardized sets of molecular markers and genetic parameters would greatly improve our understanding of patterns of genetic variation across areas of peach palm distribution and the center(s) of its domestication (Clement et al. 2010).

Diversity studies confirm the close relationship between wild and cultivated peach palm populations that were identified by Couvreur et al. (2007) in their phylogenetic study. Several studies observed even greater similarity between cultivated populations and nearby natural populations than between geographically more distant cultivated populations (Rodrigues et al. 2004; Couvreur et al. 2006; Hernández-Ugalde et al. 2008; Araújo et al. 2010). In some cases clear differences were observed between cultivated populations and wild populations that were used as outliers for reference (Silva 2004). One explanation of this close relationship is the hypothesis of peach palm's domestication in multiple locations, where cultivated populations are still closely related to nearby natural populations (Mora-Urpí 1999; Hernández-Ugalde et al. 2011). This similarity might also be the result of introgression between natural and cultivated populations after the domesticated material was introduced into a particular area (Couvreur et al. 2006). Another explanation could be that some of these natural populations are in reality feral populations, i.e., material from cultivated populations that have gone wild. This has been reported for several fruit tree species such as olives (Gepts 2004). However, considering the level of domestication of peach palm, this last option seems unlikely.

The fact that wild and cultivated populations are so closely related suggests that many cultivated peach palm populations are at a semi-domesticated stage. At this stage introgression with natural populations is still common, and while genetic diversity is reduced, phenotypic diversity may be enhanced (Clement et al. 2010). Indeed, much phenotypic variation can be observed between and within different cultivated populations (Mora-Urpí et al. 1997; Fig. 2). Particularly in the upper Amazon many landraces have been distinguished on the basis of morphological variation validated by molecular markers (Sousa et al. 2001; Rodrigues et al. 2004; Silva 2004; Clement et al. 2010). Traditionally cultivated populations can be distinguished in landraces that have (i) fruits smaller than $20 \mathrm{~g}$ (microcarpas) occurring in different parts of the distribution range, (ii) intermediate fruits between 20 and $70 \mathrm{~g}$ occurring across the whole distribution range (mesocarpas), and (iii) large fruits between 70 and $250 \mathrm{~g}$ occurring in the northwestern Amazon (macrocarpas) (Mora-Urpí et al. 1997; Rodrigues et al. 2004; Silva 2004). Fruit size also indicates the extent to which a population has been modified due to human selection during domestication (Clement et al. 2010). Couvreur et al. (2006) identified fruit size as the main characteristic differentiating wild from cultivated peach palm. A study conducted in Ecuador found that the fruit volumes of cultivated individuals are 12-33 times bigger than for wild individuals (70 vs. $2.1-5.5 \mathrm{~cm}^{3}$ ). Although peach palm is also cultivated in the Guyanas, we could not find information about particular peach palm landraces or wild populations in this region. Wild Brazilian populations were sought close to the border with French Guiana but without success (Clement et al. 2009). There is no evidence suggesting 


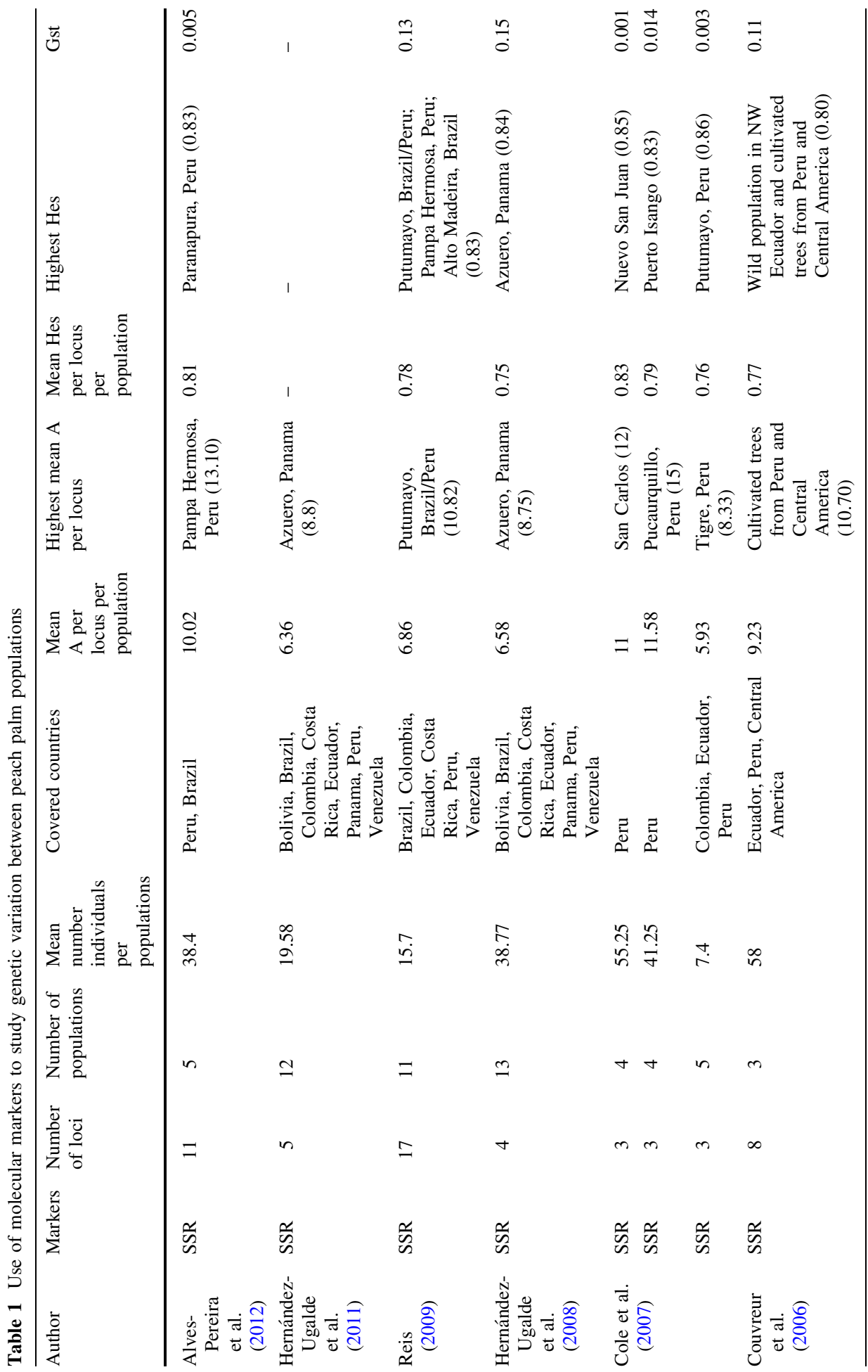




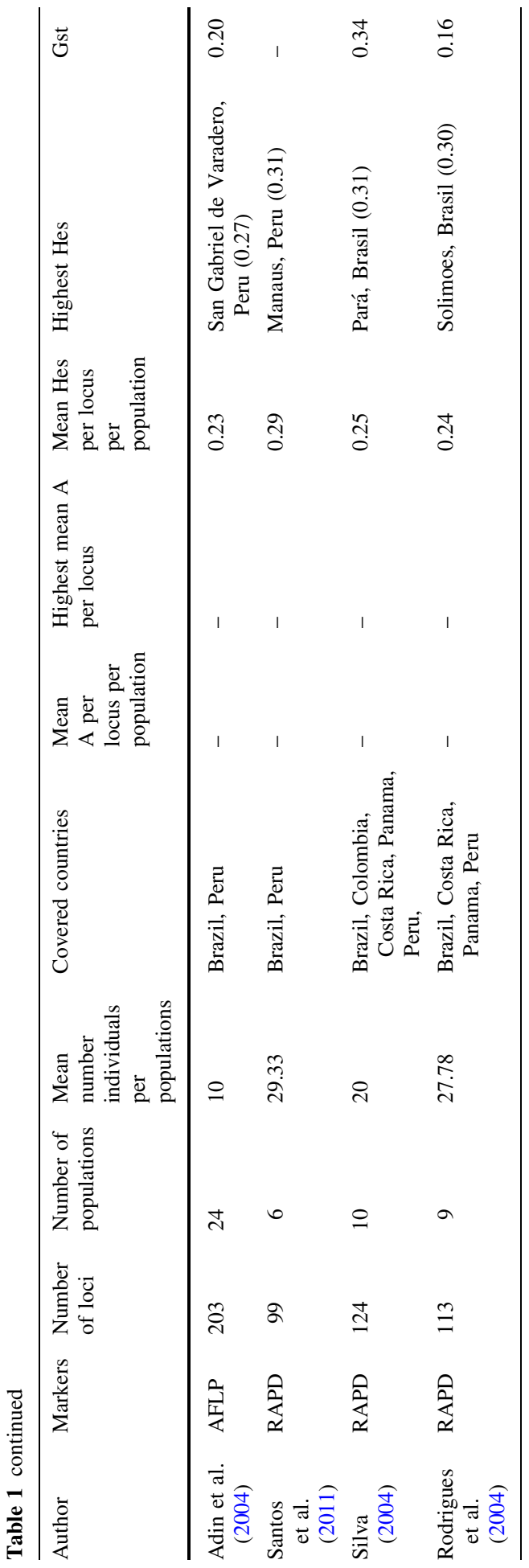


whether this part of the distribution range belongs to an existing population or forms a distinct one.

\section{Conservation and use of genetic resources}

Ex situ germplasm collections, which consist of accessions collected from different areas growing in the same field, maintain high levels of peach palm phenotypic variation (Fig. 2). Mora-Urpí et al. (1997) estimated that a total of 3,309 peach palm accessions with passport data are currently being conserved in 17 collections distributed over eight countries (i.e., Brazil, Colombia, Costa Rica, Ecuador, Nicaragua, Panama, Peru and Venezuela). A more recent overview of peach palm collections in the Amazon basin reported 2,006 accessions conserved in ten collections, including a collection in Bolivia of 200 accessions (Scheldeman et al. 2006).

Maintaining ex situ collections is costly (Clement et al. 2001; Van Leeuwen et al. 2005). Clement et al. (2004) stated that there is no justification for establishing so many collections of such large size for an underutilized tree crop like peach palm. Smaller genebanks might better address farmers' needs and consumer preferences (Clement et al. 2004; Van Leeuwen et al. 2005). Smaller collections that capture most of the genetic variation in current germplasm collections offer a good option for reducing maintenance costs (Clement et al. 2001). To assure that these collections adequately represent the existing diversity, accessions need to be screened using molecular markers for morphological and biochemical characteristics of interest that show high rates of heritability. This is already being done for the collection of the Instituto Nacional de Pesquisas da Amazônia (INPA) in Brazil (Reis 2009; Araújo et al. 2010).

Most peach palm collections from the Amazon have been characterized (Table 2; Scheldeman et al. 2006). Several have been characterized explicitly to identify materials that show promise for cooking and flour production. Fruit products are destined above all for local markets and only to a lesser extent for national or international markets. Characterizing peach palm collections is a first step toward enhance the use of conserved material. Ideally, this should involve an iterative dialogue between researchers, producers and customers. Participatory domestication of agroforestry species offers a useful tool for better enabling small-scale producers to enhance their livelihoods through sustained improvement in productivity while at the same time conserving genetic resources on farm (Weber et al. 2001). In 1997, the World Agroforesty Centre (ICRAF) and Peru's National Institute for Agricultural Research (INIA) initiated participatory genetic improvement for peach palm heart production and fruit harvesting in the Peruvian Amazon (Weber et al. 2001; Cornelius et al. 2010).

Cultivated populations contain high levels of diversity in comparison to natural populations and also maintain many traits that people have selected locally (Rodrigues et al. 2004; Couvreur et al. 2006; Hernández-Ugalde et al. 2008, 2010; Araújo et al. 2010). At the same time low genetic differentiation and the exchange of seed material over extensive areas have been observed, at least in the Peruvian Amazon (Adin et al. 2004; Cole et al. 2007). Since peach palm, as a perennial, has a lengthy generation period, the risk of genetic erosion in cultivated populations is low, so on-farm conservation might be a good alternative for large germplasm collections (Van Leeuwen et al. 2005). This requires proper management of the genetic resources to keep the risk of genetic erosion low (Cornelius et al. 2006). These same authors compared the effects of different genetic improvement strategies on the trade-offs between genetic gain in cultivated peach palm populations and conservation of genetic resources in the Peruvian Amazon. Clonal seed orchards with 

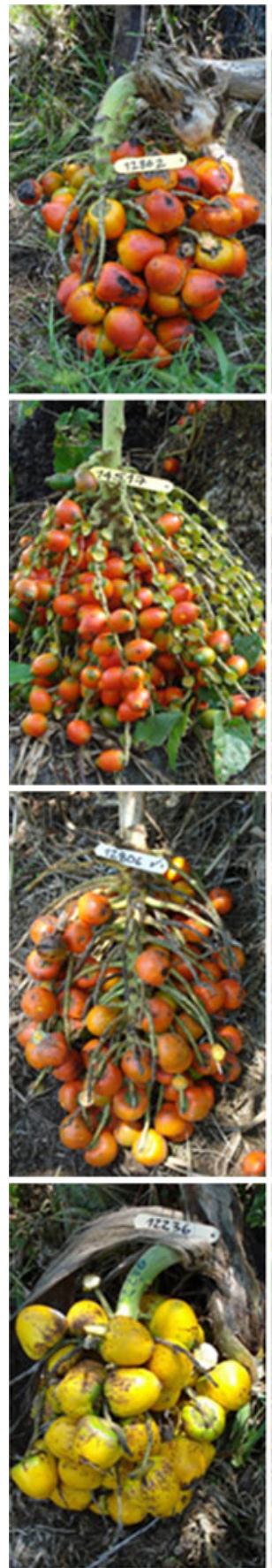
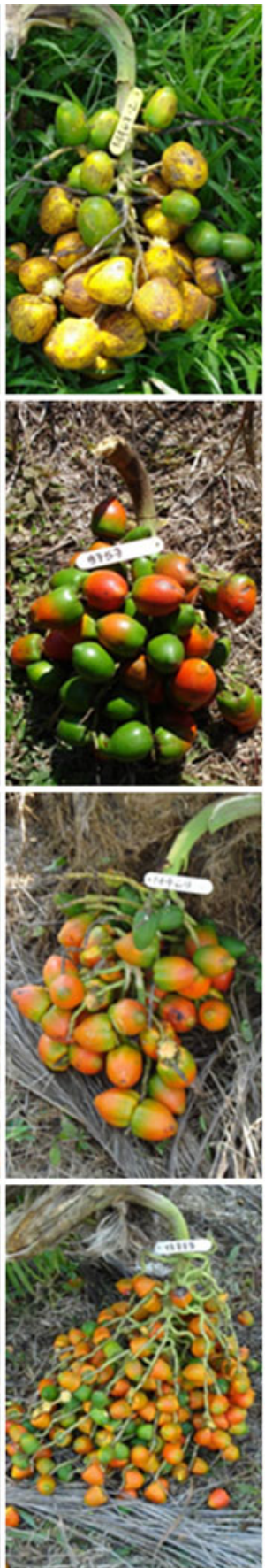
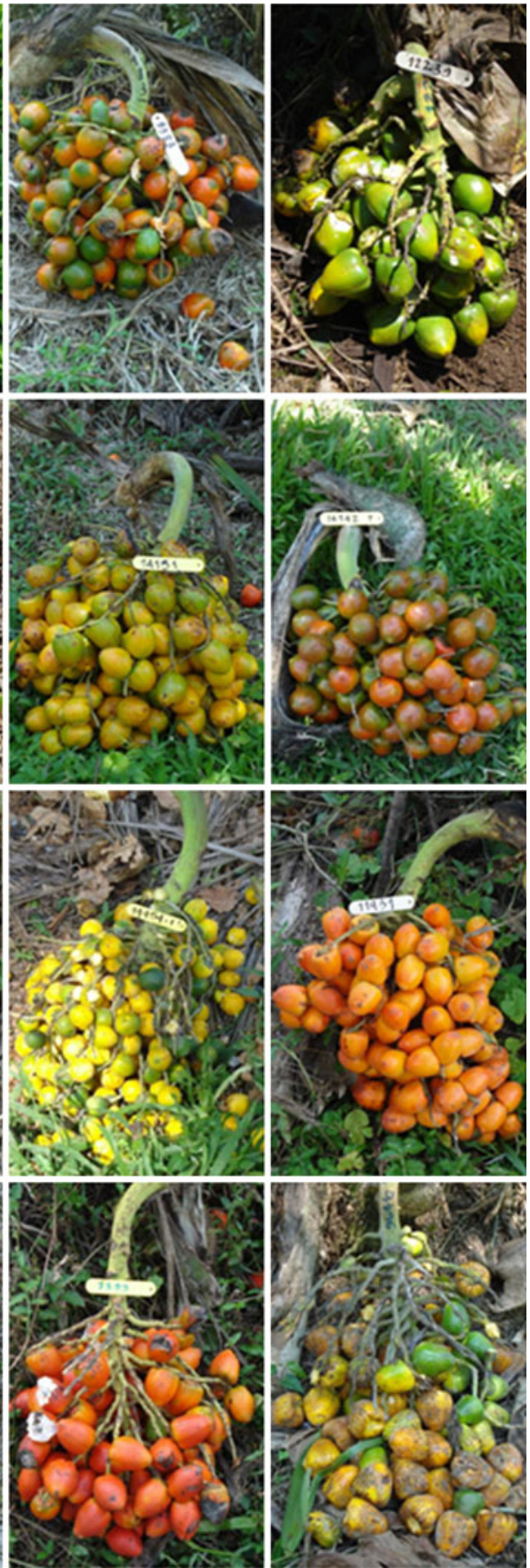

Fig. 2 Mature fruit bunches of cultivated peach palm accessions with different country origin that are conserved in the peach palm genebank collection of the Centro Agronómico Tropical de Investigación y Enseñanza (CATIE) in Costa Rica (Photos courtesy Xavier Scheldeman and Jesus Salcedo) 


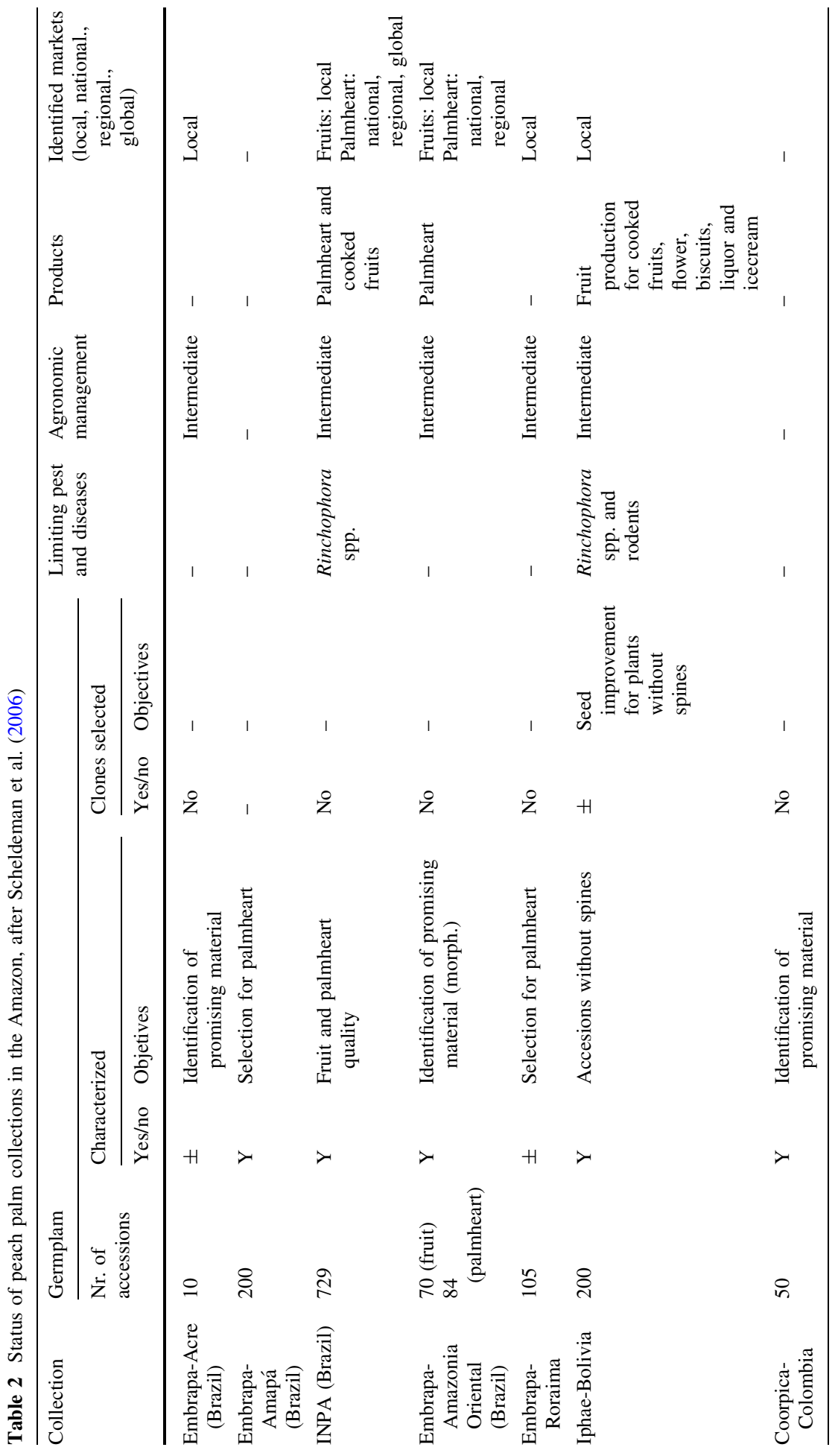




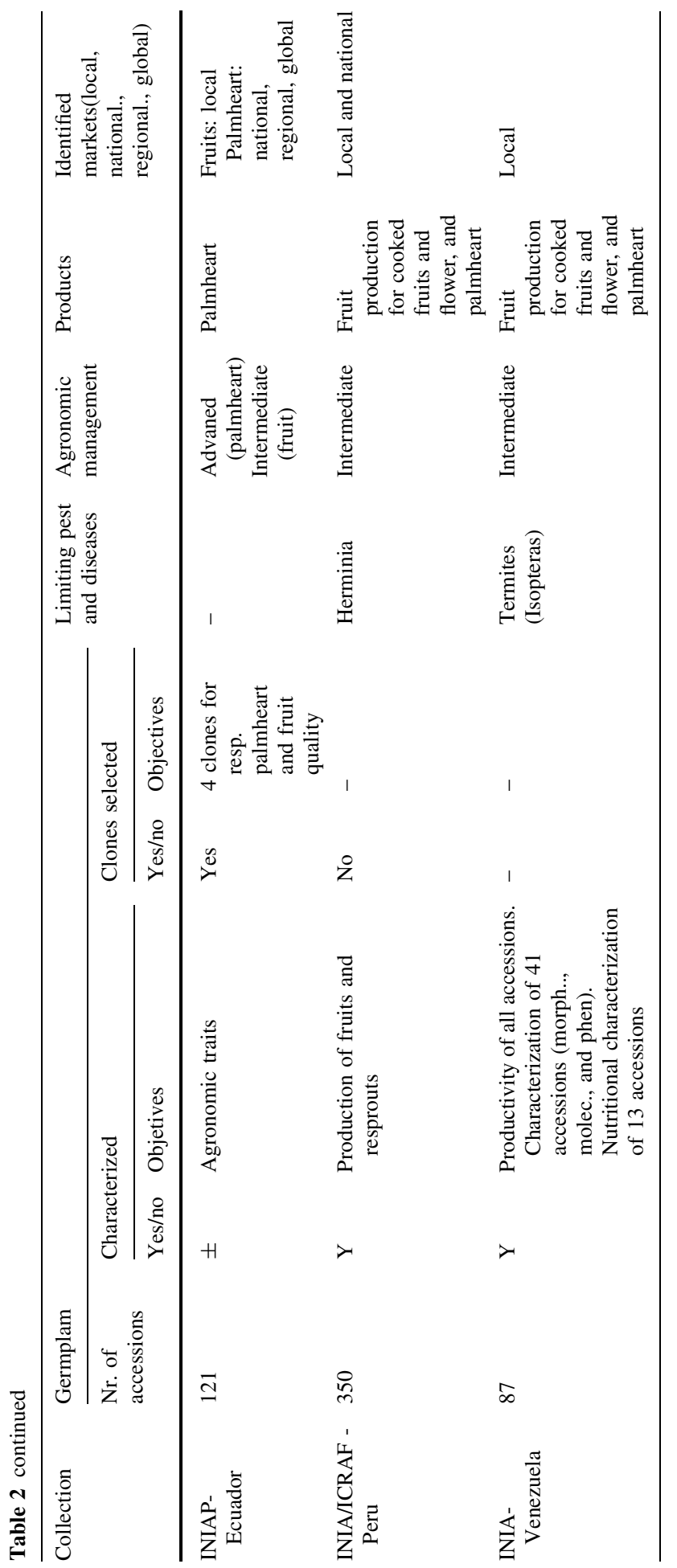


associated progeny trials based initially on 450 or more trees could be effective for achieving genetic gain while minimizing genetic erosion. However, this strategy requires vegetative propagation for multiplication (Mora-Urpí et al. 1997; Cornelius et al. 2006). Botero Botero and Atehortua (1999) reported on somatic embryogenesis in peach palm, but this technology is apparently not used to multiply selected accessions. Only in one collection have clones been selected for propagation (Table 2). Nevertheless, research is underway to further improve techniques, such as somatic embryogenesis, for clonal propagation (Steinmacher et al. 2007, 2011).

In contrast to cultivated peach palm, wild populations (being important resources for genetic improvement) are threatened by deforestation, driven mainly by agricultural expansion and the transition of forest to savannah (Clement et al. 2009). How this threat affects the three taxonomically different wild types (see Henderson 2000) is not clear, because their distribution is not yet well defined (Clement et al. 2009). Wild peach palm trees are found in disturbed ecosystems, on river banks and in primary forest gaps (Mora-Urpí et al. 1997). They often occur in isolation or at low densities (Mora-Urpí et al. 1997; Da Silva and Clement 2005). Though no definitive studies have been conducted on seed dispersal of peach palm, it is probably restricted locally to dispersal by birds and seed-gathering mammals, though seed may occasionally be dispersed by water, potentially over greater distances (Mora-Urpí et al. 1997; Clement et al. 2009). Gene flow of outcrossing tree species with this type of scattered distribution may be restricted and could result in genetically distinct isolated subpopulations with small effective population sizes (Mora-Urpí et al. 1997). This has implications for conservation strategies, which require further research. It is probably too expensive to conserve ex situ a significant number of wild palm accessions; strategies that maximize in situ conservation of wild populations seem more feasible. Optimization analysis, as proposed by Weitzman (1998), could help determine which populations can best be conserved in situ, considering the genetic distinctiveness of each population compared to others and the costs of implementing conservation measures that guard effectively against human pressures and progressive climate change. On-farm conservation could be an appropriate alternative for in situ conservation of wild populations, particularly if high levels of diversity are maintained in nearby cultivated populations and these are genetically close to wild populations (Hollingsworth et al. 2005). Indeed, in many regions cultivated peach palm populations are closely related to nearby wild populations (Couvreur et al. 2006; HérnandezUgalde et al. 2008, 2011) and they could complement in situ conservation of the wild populations that are genetically most distinct and most at risk of extinction.

\section{Peach palm fruit production}

\section{Production systems}

Given its rapid juvenile growth (1.5-2 $\mathrm{m} \mathrm{year}^{-1}$ ) and moderate light interception when spaced appropriately, peach palm may be considered a promising tree for canopy strata in agroforestry systems (Clement 1989; Cordero et al. 2003; Clement et al. 2004). Table 3 summarizes the wide range of species associations that are encountered in peach palm production systems of Central and South America. Highly adaptable and productive, with multiple uses and strong market potential, the species also shows promise for the introduction of new agroforestry systems and restoration of deforested sites (Vélez and Germán 1991).

In Costa Rica and Colombia, peach palm is commonly cultivated with coffee and banana, and in Brazil, it is recommended as a shade tree for cacao (Clement 1986). In the 
Table 3 Common species associations in traditional, commercial and experimental peach palm production systems

\begin{tabular}{|c|c|c|c|}
\hline Common name & Scientific name & Location & Source \\
\hline \multicolumn{4}{|c|}{ Traditional agroforestry systems } \\
\hline Cassava & Manihot esculenta & \multirow{8}{*}{$\begin{array}{l}\text { Peruvian Amazon } \\
\text { (indigenous market } \\
\text { oriented system) }\end{array}$} & \multirow[t]{8}{*}{ Coomes and Burt (1997) } \\
\hline Yam & Dioscorea alata & & \\
\hline Plantain & Musa spp. & & \\
\hline Pineapple & Ananas comosus & & \\
\hline Cashew & Anacardium occidentale & & \\
\hline Guava & Inga edulis & & \\
\hline Umarí & Pouraqueiba sericea & & \\
\hline Macambo & Theobroma bicolor & & \\
\hline Borojo & Borojoa patinoi & \multirow[t]{4}{*}{ Colombian Pacific Region } & \multirow[t]{4}{*}{ CIAT, unpublished data } \\
\hline Taro & Colocasia esculenta & & \\
\hline Musaceas & Musa spp. & & \\
\hline Araza & Eugenia stipitata & & \\
\hline Cacao & Theobroma cacao & \multirow{8}{*}{$\begin{array}{l}\text { Limón, Costa Rica } \\
\text { (Tayní indigenous } \\
\text { community) }\end{array}$} & \multirow[t]{8}{*}{ Cordero et al. (2003) } \\
\hline Banano & Musa spp. & & \\
\hline Café & Coffea arabica & & \\
\hline Guaba & Inga spp. & & \\
\hline Hule & Castilla costarricense & & \\
\hline Laurel & Cordia alliodora & & \\
\hline Pilón & Hyeronima alchorneoides & & \\
\hline Cachá & Abarema idiopodia & & \\
\hline Cacao & Theobroma cacao & \multirow{5}{*}{$\begin{array}{l}\text { Bocas del Toro, Panamá } \\
\text { (Teribe indigenous } \\
\text { community) }\end{array}$} & \multirow[t]{5}{*}{ Cordero et al. (2003) } \\
\hline Orange & Citrus sinensis & & \\
\hline Plantain & Musa spp. & & \\
\hline Banana & Musa spp. & & \\
\hline Laurel & Cordia alliodora & & \\
\hline \multicolumn{4}{|c|}{ Commercial plantations } \\
\hline Coffee & Coffea arabica & \multirow[t]{2}{*}{ Costa Rica } & \multirow[t]{2}{*}{ Clement (1986) } \\
\hline Banana & Musa spp. & & \\
\hline Pineapple & Ananas comosus & \multirow{7}{*}{$\begin{array}{l}\text { Several countries in Central } \\
\text { and South America } \\
\text { (short cycle crops enrich } \\
\text { Bactris plantations during } \\
\text { the early years for a better } \\
\text { economic return) }\end{array}$} & \multirow{7}{*}{$\begin{array}{l}\text { Clement (1986) } \\
\text { Clement (1989) }\end{array}$} \\
\hline Papaya & Carica papaya & & \\
\hline Passion fruit & Passiflora edulis & & \\
\hline Rice & Oryza spp. & & \\
\hline Beans & Phaseolus spp. & & \\
\hline Maize & Zea mays & & \\
\hline Cassava & Manihot esculenta & & \\
\hline Cacao & Theobroma cacao & Whole Amazon region & Clement (1989) \\
\hline Cupuassu & Theobroma grandiflorum & Brazilian Amazon & McGrath et al. (2000) \\
\hline
\end{tabular}


Table 3 continued

\begin{tabular}{|c|c|c|c|}
\hline Common name & Scientific name & Location & Source \\
\hline \multicolumn{4}{|c|}{ Experimental agroforestry systems } \\
\hline Kudzu & Pueraria phaseoloides & \multirow[t]{4}{*}{ Brazilian Amazon } & \multirow[t]{4}{*}{ Lieberei et al. (2000) } \\
\hline Achiote & Bixa orellana & & \\
\hline Brazil nut & Bertholletia excelsa & & \\
\hline Cupuaçu & Theobroma grandiflorum & & \\
\hline Coconut & Cocos nucifera & \multirow[t]{5}{*}{ Brazilian Amazon } & \multirow[t]{5}{*}{ Clement (1986) } \\
\hline Uvilla & Pourouma cecropiaefolia & & \\
\hline Cupuassu & Theobroma grandiflorum & & \\
\hline Graviola & Annona muricata & & \\
\hline Biriba & Rollinia тисоsa & & \\
\hline Breadfruit & Artocarpus altilis & \multirow{2}{*}{$\begin{array}{l}\text { Brazilian Amazon } \\
\text { ("food forest" experiment) }\end{array}$} & \multirow[t]{2}{*}{ Arkoll (1982) } \\
\hline Jackfruit & Artocarpus heterophyllus & & \\
\hline Cacao & Theobroma cacao & \multirow[t]{2}{*}{ Bahia, Brazil } & \multirow[t]{2}{*}{ Alvim et al. (1992) } \\
\hline Black pepper & Piper nigrum & & \\
\hline Cassava & Manihot esculenta & \multirow[t]{4}{*}{ Pucallpa, Peru } & \multirow[t]{4}{*}{ Pérez and Loayza (1989) } \\
\hline Chiclayo & Vigna sinensis & & \\
\hline Pigeon pea & Cajanus cajan & & \\
\hline Pineapple & Ananas comosus & & \\
\hline Guava & Inga edulis & $\begin{array}{l}\text { Pucallpa, Peru (natural } \\
\text { terraces for erosion control) }\end{array}$ & $\begin{array}{l}\text { Vargas and Aubert } \\
\text { (1996) }\end{array}$ \\
\hline
\end{tabular}

Brazilian Amazon, Lieberei et al. (2000) identified peach palm grown with Pueraria phaseoloides, Bixa orellana, Bertholletia excelsa and Theobroma grandiflorum as a promising multi-strata system for optimal resource cycling. Peach palm can be also cultivated with coconut as well as with various short-cycle crops, such as pineapple, papaya, and passion fruit, which give farmers rapid returns on investment in the early years of production (Clement 1986).

In the Colombian Pacific region, farmers typically cultivate peach palm with Borojoa patinoi, Colocasia esculenta, Musa spp. and Eugenia stipitata. In those agroforestry systems peach palm occupies around $38 \%$ of the available space in farmers' fields (CIAT, unpublished data). In the Peruvian Amazon peach palm is cultivated within agroforestry mosaics that are characterized by several components, such as annual subsistence crops (e.g., manioc, yam and plantain), fruit crops (e.g., pineapple, cashew and guava), and latematuring fruit trees (e.g., Pouraqueiba sericea and Theobroma bicolor). In such agroforestry systems peach palm is grown at a density of approximately 290 trees ha $^{-1}$ (Coomes and Burt 1997), though in most traditional Amazonian agroforestry systems densities of only 3-20 plants ha ${ }^{-1}$ have been reported (Clement 1989; Clay and Clement 1993).

Peach palm is also commonly cultivated in monoculture, with an average plant density of around 400 plants ha $^{-1}$ (Mora-Kopper et al. 1997; Clement et al. 2004). Peach palm in monoculture tends to be smaller than in multi-strata systems, primarily because of less competition for light (Schroth et al. 2002a). 
In Colombia peach palm is planted for fruit production on an estimated 9,580 ha, with $73 \%$ on the Pacific coast, $22 \%$ in the Amazon region, and the rest (5\%) in other regions of the country. Reported yields vary between 3.0 and $20.0 \mathrm{t} \mathrm{ha}^{-1}$ (MADR 2009), although this figure does not take into account areas planted for subsistence. Peach palm is found scattered within highly diverse agroforestry and home garden systems, where its extent is difficult to measure (Clement et al. 2004).

\section{Management}

Peach palm does not appear to require much care, though mulching around the base of the trees is recommended to control weeds. When peach palm is grown at low densities in mixed cropping systems, it remains relatively free of pests. Rats may cause serious damage, however, by climbing the palms and eating the fruits (Almeyda and Martin 1980). On the Colombian Pacific coast Palmelampius heinrichi, which causes unripe fruits to fall from the palms, poses a serious threat, forcing farmers to apply large amounts of insecticides. Reports indicate that this pest has completely destroyed peach palm plantations in several regions of Colombia (Lehman Danzinger 1993; O'Brien and Kovarik 2000; Constantino et al. 2003). Some farmers have adopted the recommended practice of protecting the inflorescenses from $P$. heinrichi with blue translucent plastic bags, which remain around the bunch until harvest (Peña et al. 2002). Other pests known to affect peach palm production are Rhinostomu barbirostris (bearded weevil) and Alurnus sp. (known locally as "gualapan") (Pardo Locarno et al. 2005).

Commercial fruit production usually starts 3-5 years after planting and lasts for 50-75 years (Patiño 2000; Ares et al. 2003; Cordero et al. 2003). Fruit bunches may weigh up to $12 \mathrm{~kg}$, but this varies greatly, depending on tree origin and management. Though bunches with 420 fruits have been reported (Clement et al. 2010), peach palm typically produces 75-300 fruits per bunch (Almeyda and Martin 1980; Arkcoll and Aguiar 1984). Fruit diameter varies from 1 to $9 \mathrm{~cm}$, and mean fruit weight normally ranges from 20 to $65 \mathrm{~g}$, though fruits may weigh up to $225 \mathrm{~g}$ (Fig. 3; Arkcoll and Aguiar 1984; Leterme et al. 2005; Rivera 2009).

One issue in peach palm fruit cultivation is the number of stems to maintain (multiplevs. single-stemmed plantings). Monocultures are usually single stemmed (with planting distances typically $5 \times 5$ or $6 \times 6 \mathrm{~m}$ ), whereas in agroforestry systems palms may be either single- or multi-stemmed (Clay and Clement 1993). The palms reach their maximum stem diameter at an age of around 2.5 years; afterwards, only tree height increases (Pérez and Davey 1986). Each stem produces about seven bunches during the principal harvest and three in the secondary harvest. If several stems are permitted to grow, the yield is greater than that of a single stem, but harvest is more difficult (Clement et al. 2010). In the coffee growing region of Colombia peach palm farmers usually keep four stems per plant, using the central stem to climb the tree and harvest bunches from the surrounding stems. Germplasm that varies in height could facilitate harvesting and thus increase commercial exploitation. Harvesting is usually considered the most difficult operation in peach palm production, as the spines and height of the palms represent safety hazards (Box 1). Men usually harvest the fruit, with help from younger family members.

\section{Biomass}

Due to its perennial nature and high biomass accumulation peach palm for fruit production could act as an important carbon sink in land use systems. Crop growth rates depend on the 

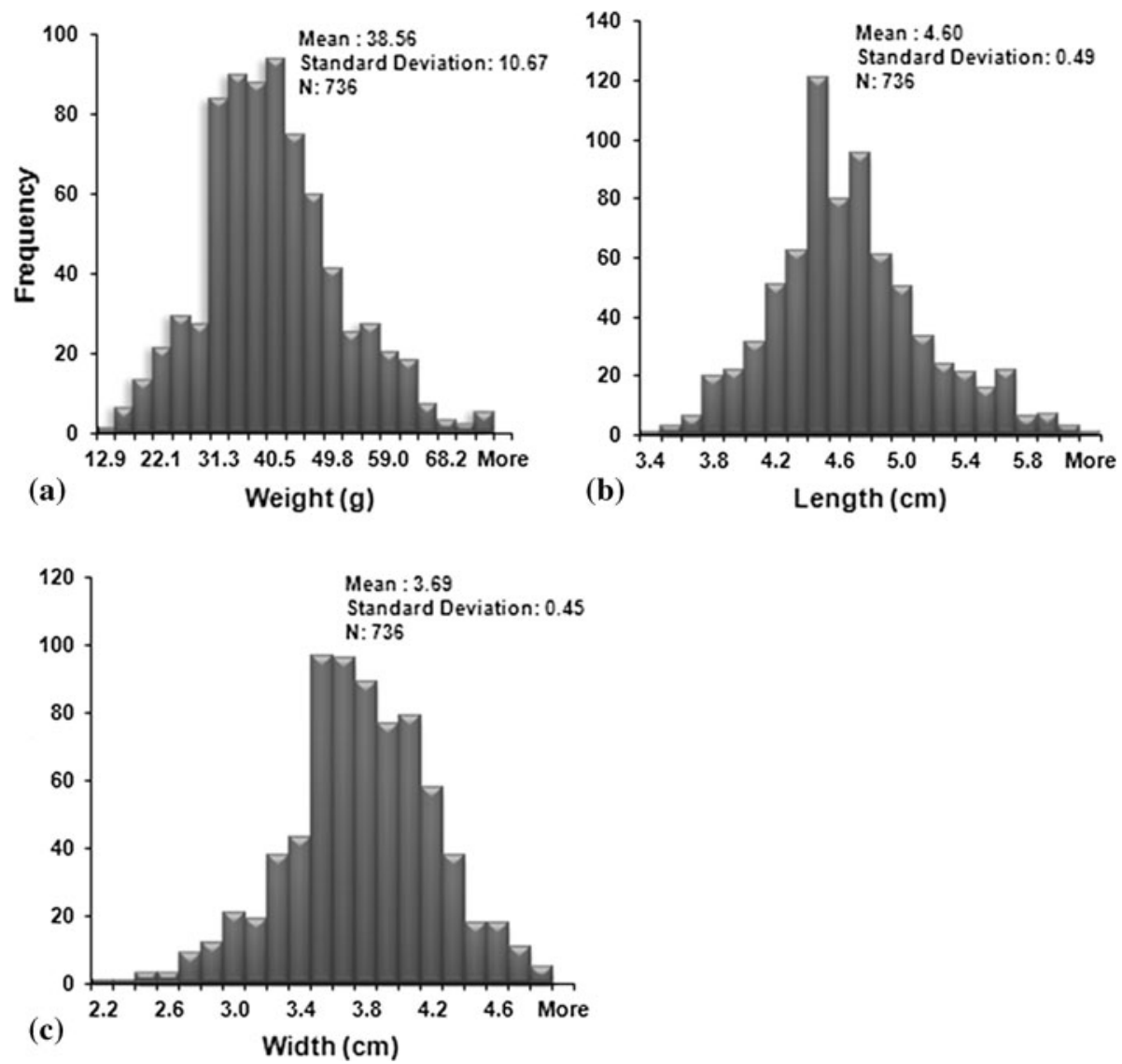

Fig. 3 Distribution curves of weight (a), length (b) and width (c) in peach palm fruits

Box 1 Methods for harvesting peach palm fruits

\footnotetext{
Rural communities employ a variety of methods for harvesting peach palm. In Peru, Costa Rica and some areas of Colombia fruits are harvested from the ground using a stick (normally of bamboo) 7-13 m long. A hook-shaped piece of wood is attached to the top of the bamboo stick (usually two branches with an insertion angle of $45^{\circ}$ ). The hook is used to pull down the peduncle and detach the bunch from the palm. Experienced harvesters can keep the bunch attached to the hook, but often it falls to the ground, where it is caught by two or more people holding a blanket. When the hook remains attached to the bamboo stick, the farmer must swing the stick to the ground, a task requiring considerable strength and time. At some locations in Colombia, farmers climb the palm tree to harvest the fruits, using two triangle-shape frames made of three logs each. Two corners of the triangle are secured with a wire; the third is kept untied so the triangle structure can be placed around the tree. Once this is accomplished, the open corner is secured with a rope, which is also wrapped around the trunk of the palm tree. To avoid damage, the rope is sometimes protected by coiling wire around it. The two triangles support the palm tree climbers, who pull up the lower triangle with their feet and then push up the upper triangle using their hands until they reach the bunches. This practice requires the removal of spines from the trunk, a practice that seems to attract pests because of volatiles released from the trunk. While skillful harvesters often use this method without major problems, accidents are common and may result in serious injuries. To make harvesting safer and more efficient, new devices are being designed with communities actively involved in design and testing.
} 
number of stems maintained, varying from $15.6 \mathrm{t} \mathrm{ha}^{-1}$ year $^{-1}$ for single-stemmed to $54.3 \mathrm{t} \mathrm{ha}^{-1}$ year $^{-1}$ for four-stemmed palms grown at a distance of $8 \times 8 \mathrm{~m}$ in the Amazon region (Clement 1986). Haag (1997) reported above-ground biomass of 16.0-33.5 kg dry matter tree ${ }^{-1}$ and a root:shoot ratio of 0.3 for peach palm grown in Central Amazonia. Postma and Verheij (1994) evaluated the growth of peach palm in swidden fields in the Colombia Amazon. This enabled the authors to fit growth curves of the species, revealing that the environment affects peach palm much less than other species.

Peach palm monocultures in the Brazilian Amazon accumulated biomass stocks of $80 \mathrm{t} \mathrm{ha}^{-1}$, less than the biomass of the secondary forests replaced $\left(127.5 \mathrm{t} \mathrm{ha}^{-1}\right)$. Peach palm accumulated carbon much faster $\left(5.1 \mathrm{t} \mathrm{C} \mathrm{ha}^{-1}\right.$ year $\left.^{-1}\right)$, however, than in successional vegetation $\left(4 \mathrm{tha}^{-1}\right.$ year $^{-1}$ ), mainly due to high plant densities in monocultures (625 trees $\mathrm{ha}^{-1}$ ) and also fertilizer inputs. One disadvantage of accumulating carbon stocks in peach palm production systems is that tree height may severely limit fruit harvest, with the consequence that plantations have to be regenerated after approximately 10 years, which would be equivalent to a time-averaged carbon stock of about $25 \mathrm{t} \mathrm{C} \mathrm{ha}^{-1}$ (Schroth et al. 2002a).

Peach palm agroforests also show significant potential to serve as carbon sinks. According to Schroth et al. (2002a), carbon accumulation varied between 2.9 and $3.8 \mathrm{t} \mathrm{C} \mathrm{ha}^{-1}$ year $^{-1}$ in multi-strata systems of the Brazilian Amazon. In the long run the longer economic life cycle of the multi-strata system compensates for its lower carbon accumulation rate compared to monocultures. However, it is hard to measure the timeaveraged carbons stocks of those systems, as they depend on several factors, such as species composition and economic life. Given possible trade-offs between high carbon accumulation and economic production, the challenge is to find optimal combinations of shade-tolerant understory and high-value overstory trees.

Lehmann et al. (2000b) found evidence that cover crops in peach palm agroforestry systems can accumulate amounts of aboveground biomass of similar to or exceeding those of the associated trees. In a mixed cropping system with $T$. grandiflorum and B. gasipaes grown for palm heart as well as $P$. phaseoloides as a cover crop, biomass production of the cover crop accounted for $55 \%$ of the system's total biomass production.

The highest share of carbon is usually found in soil organic matter (SOM). All of the plantation systems investigated by Schroth et al. (2002a) contained twice as much carbon in SOM as in the biomass and litter combined.

\section{Nutrients}

Since little is known about nutrient demands in peach palm production systems, fertilization requirements are usually adapted either from heart of palm cultivation (Schroth et al. 2002b) or from the production of other palm fruits, such as coconut or oil palm (Ares et al., 2003). McGrath et al. (2000) identified P as the most limiting nutrient for stand growth and fruit production in low-input Amazonian peach palm agroforests. Similarly, Schroth et al. (2002b) reported that $\mathrm{P}$ and $\mathrm{Mg}$ rather than $\mathrm{N}$ fertilization influenced yields in heart of palm production systems. In the Central Amazon region of Brazil annual doses of $125-225 \mathrm{~kg} \mathrm{~N}, 20-40 \mathrm{~kg} \mathrm{P}$, and $60-150 \mathrm{~kg} \mathrm{~K}^{-1}$ were required to sustain peach palm growth in a monoculture system (Ares et al. 2003). Clay and Clement (1993) reported nutrient requirements of $200 \mathrm{~g} \mathrm{P}, 150 \mathrm{~g} \mathrm{~N}$ and $\mathrm{K}$, and about $50 \mathrm{~g} \mathrm{Mg}$ per year for singlestemmed palms on nutrient-poor Oxisols near Manaus, Brazil. National agricultural research institutions typically recommend fertilizer applications of $2 \mathrm{~kg} \mathrm{15-15-15} \mathrm{or} 5 \mathrm{~kg}$ 10-10-9 NPK tree ${ }^{-1}$ year $^{-1}$ (Almeyda and Martin 1980; Acevedo et al. 1996). Within- 
plant nutrient re-translocation is likely to be greater in peach palm fruit systems than in heart-of-palm systems, because the former have more fallen leaves (Ares et al. 2003). Litter in the fruit system is low in nutrients, however, and may decompose more slowly than in the heart-of-palm system (McGrath et al. 2000). Peach palm has a superficial but extensive root system, which is adapted to little-developed soils (FAO 1983). Rooting depth was reported to be less than $0.7 \mathrm{~m}$, with an average root length of around $6 \mathrm{~m}$ (INCIVA 1982). Depending on soil conditions peach palm can also extend its roots into the subsoil. Lehmann et al. (2001) found that peach palm shows its greatest root development at soil depths of $60-150 \mathrm{~cm}$ in a multi-layer agroforestry system with $T$. grandiflorum and B. excelsa. As the associated species developed roots mainly in the topsoil, one can assume that their nutrient uptake complements that of peach palm. One peculiarity of its root system is that the root mat rises above the soil surface (Mora-Kopper et al. 1997). Fallen leaves and other debris accumulate and decompose on this superficial mat, providing a pool of nutrients that has little contact with the soil but can serve as an important source of $\mathrm{P}$ in the system (McGrath et al. 2000). Lehmann et al. (2000a) found that $70 \%$ of the total $\mathrm{N}$ uptake occurred from the areas underneath the peach palm canopy. The $\mathrm{N}$ turnover of peach palm was calculated on the basis of litterfall data at $90 \mathrm{~kg} \mathrm{ha}^{-1}$ year $^{-1}$ in a heart-ofpalm agroforest. Lehmann et al. (2000a, b) have further highlighted the role of cover crops in peach palm agroforesty systems. $P$. phaseoloides, which was planted as a legume cover crop in a Theobroma grandiflorum-Bactris (palm heart) agroforestry system, proved to be very important for $\mathrm{N}$ cycling, as it accumulated $83 \%$ of total $\mathrm{N}$ and contributed $66 \%$ of total $\mathrm{N}$ turnover in this mixed cropping system. Several authors identified Centrosema macrocarpum and $C$. pubescens as promising leguminous species for peach palm production systems (Domínguez 1990; INIAA 1990; IIAP 1995), delivering nutrients while also suppressing weeds and improving the phytosanitary condition of plantations. Inoculating plantlets with mycorrhiza is highly recommended in peach palm nurseries to enhance seedling growth and reduce the time to field transplanting (Ydrogo 1994; Salamanca and Cano 2005).

\section{Socio-economic aspects of peach palm}

Though no authors have published exact figures on the importance of peach palm consumption and commercialization for local economies, several have presented evidence that the tree forms an important part of subsistence and commercial livelihood strategies in areas where it is cultivated (Mejía 1978; Velasco et al. 1980; Patiño 2000; Medina et al. 2007; Zambrana et al. 2007). In the Peruvian Amazon (Yurimaguas, Iquitos) more than $80 \%$ of farmers cultivate peach palm (Labarta and Weber 1998) and consider it to be one of the most important species in their agroforestry systems, accounting for the second highest share of production volume after plantain. However, outside the Amazon region in Peru peach palm is not widely recognized. According to a survey conducted in the country's capital, Lima, only $2 \%$ of those interviewed were aware of peach palm fruit consumption (Lopez and Lozano 2005).

Evidence from Brazil suggests that the closer peach palm producers are to urban centers, the higher the incomes they expect from its cultivation. For producers far away from urban areas peach palm will likely remain a subsistence crop, which cannot compete with processed starch products (Clement 2006). A peach palm-black pepper-cacao plantation in the Brazilian state of Bahia showed positive economic returns from the fourth year onwards (Alvim et al. 1992). A report from Costa Rica also underscores the economic 
potential of peach palm, indicating a fruit yield of $10 \mathrm{t} \mathrm{ha}^{-1}$ and gross income of about 3,000 US- $\$$ ha $^{-1}$ year $^{-1}$ (Cordero et al. 2003).

Market demand for freshly cooked fruit is estimated at about 20,000 t per year in Colombia, and the demand is increasing (Clement et al. 2004). In Brazil market studies on peach palm show that the demand for fresh fruit has remained stable during the past 50 years (Clement and Santos 2002). However, reports of overproduction have come from Colombia and Brazil (Clement and Santos 2002; Godoy et al. 2007). There is no international market for peach palm fruits.

In Colombia peach palm cultivation is more market oriented on the Pacific coast than in the Amazon region (Clement et al. 2004). That is especially the case in the municipality of Buenaventura (Department of Valle del Cauca), where peach palm is very widely cultivated. In the more northern Chocó region, in contrast, production is destined more for home consumption (Patiño 2000). Colombia's Pacific coast is one of the country's poorest and most marginalized regions and among those most affected by conflicts resulting from drug trafficking and the presence of guerilla and paramilitary groups. Under those conditions, the peach palm has gained particular economic importance. The region's climatic and edaphic conditions (including precipitation of about 8,000 mm year ${ }^{-1}$ and acid soils) make it poorly suited for commercial agriculture, and its predominantly Afro-Colombian population lives in small settlements scattered along rivers. Farmers cultivate peach palm in small orchards and home gardens, using traditional management practices, which usually do not include seed selection. The fruit forms part of rural diets and represents the main source of income during harvest (Mejía 1978; CIAT, unpublished).

The city of Cali reports the highest levels of peach palm consumption in Colombia (Clement et al. 2004; Quintero 2008), with a sales volume estimated at around 10 million dollars year ${ }^{-1}$ (CIAT, unpublished). Nearby cities (e.g., Palmira, Pradera, Popayán and Armenia) represent emerging markets for cooked peach palm fruits. In Bogotá, Colombia's capital and largest city, cooked fruits are sold in several places. Even in large franchise restaurants the fruit is an ingredient of some dishes. Most of the fruits consumed in Cali come from municipalities around Buenaventura on the Pacific Coast, though the city's markets also provide fruits from quite distant regions. The harvested fruit bunches are usually transported by boat to small river ports connected to the road network; from there they are commercialized through local intermediaries and transported to the city (135 km on paved road). In 2009 farmers obtained around $0.60-0.90$ US-\$ for $1 \mathrm{~kg}$ of fruits. In Cali several peach palm traders are located at a place named "Puerto Chontaduro," where much of the city's peach palm supply is sold. One or two intermediaries merchandise the fruit again until it is finally sold to street vendors (Giraldo et al. 2009). In Cali women referred to as platoneras have exclusive control of the business, with an estimated 3000, mostly from the poorest neighborhoods, depending on this activity as their main source of income (Rodriguez et al. 2009). According to a survey conducted by the provincial government of Valle del Cauca, the majority of platoneras have poor access to education and health services and must finance their activities with informal credit at high interest rates (Gobernación Valle del Cauca 2007, unpublished).

The commercial flow of fruits from the coastal region to Cali has increased significantly in recent decades; the city now accounts for an estimated $60 \%$ of the consumption of peach palm fruits from this region. During the 1970s, in contrast, peach palm was mostly consumed in the municipality were it was cultivated $(62 \%)$ or marketed in the city of Buenaventura (34\%) (Mejía 1978). Reports from the 18th century indicate that during a period of food scarcity in Cali peach palm imports from the Buenaventura region helped end the emergency (Patiño 1995). 
Today peach palm is considered a promising substitute for illicit crops cultivated in Colombia. Earnings from peach palm production have been estimated at about 2,500 US$\$ \mathrm{ha}^{-1}$ year $^{-1}$ with yields of about $8 \mathrm{t} \mathrm{ha}^{-1}$ year $^{-1}$. One major drawback is that it takes about 7 years to reach full production, though the palm trees begin producing after the third year. Investment costs of peach palm plantations are considered reasonable at approximately 400 US- $\$$ ha $^{-1}$ (Winogrond 2004). In 2008/2009 the United Nations Office on Drugs and Crime (UNODC) reported a reduction of coca plantations in areas where peach palm was commonly grown, especially in the Amazon region (Caqueta) (UNODC 2010). On Colombia's Pacific coast peach palm is also considered to be a promising alternative crop. In the Buenaventura region, however, peach palm cultivation has declined, mainly as a result of illegal mining, which is more profitable for farmers than traditional crop cultivation. The lack of technical assistance for farmers regarding soil management, phytosantitary issues and product development has worsened the situation, further reducing investment in peach palm cultivation. Illicit crop production has brought prohibited highly toxic pesticides into the region, which farmers now use against peach palm pests.

Peach palm development appears to be following a trajectory similar to that of açaí (Euterpe oleracea), which is nowadays regarded as the most successful agroforestry crop of the Amazon region. Although peach palm development for fruit is quite advanced in some local markets (e.g., San José in Costa Rica, Manaus and Belem in Brazil, and Cali in Colombia), it has yet to reach international markets as açaí has done. Açaí first gained importance in local markets due to rural outmigration in the 1970s. Its appeal widened through a program aimed at promoting the export of Amazonian fruits in the 1980s and as a result of the green food wave in the 1990s (Brondizio 2004). Similarly, peach palm considerably expanded its presence in the local market of Cali through the migration of Afro-Colombian populations from the Pacific Coast to inland areas of the country. Migrants brought their preferred foods with them and thus promoted the consumption peach palm fruits in Cali. Now the fruit is popularly appreciated for its invigorating properties, which probably account for its widespread consumption. In recent years booths for selling cooked peach palm fruits have emerged in large supermarkets and shopping malls. As happened with açaí, new actors may be slowly gaining control of the most profitable links of the value chain, possibly to the detriment of traditional street vendors and growers.

\section{Multiple uses of peach palm}

\section{Consumer preferences and quality}

A significant weakness in the production-to-consumption chain consists of variability in fruit quality (Clement et al. 2004). Since peach palm fruits are highly perishable, getting fruits from the farm to the consumer requires careful post-harvest management. Depending on maturity and handling, peach palm fruits have a shelf life of only 3-7 days (Clement and Santos 2002; Clement et al. 2004; Quintero 2008). Another constraint is that street vendors are usually unaware of the exact origin of the fruits they purchase; they likely purchase a mix of fruits that have differing origins and vary in texture, composition and cooking time-a practice that negatively affects the quality of the cooked fruits (Quintero 2008), thus reducing consumer satisfaction. One of the most important quality parameters for street vendors is 
cooking time, which averages $2-4 \mathrm{~h}$ but may reach $5 \mathrm{~h}$. Street vendors usually cook the fruits themselves, putting in long hours and coping with high demand for energy.

Consumer demands are only now getting more attention. In general, consumers prefer red fruits to yellow ones and oily fruits to starchy ones (Clement et al. 2004). Clement and Santos (2002) confirmed those findings through an analysis of consumer preferences for peach palm in Manaus, Brazil. They found that consumers prefer red, moderately oily fruits of medium weight. Such types are difficult to breed, as size and oil are negatively correlated (Clement and Santos 2002; Cornelius et al. 2010). Moreover, the relative proportions of starch versus oil vary inversely along the domestication continuum, with fruits of wild types being rich in oils and the most domesticated types showing higher starch content (Clement et al. 2004). As a result, markets supply more of the larger, dry-textured fruits than the preferred oily types (Clement and Santos 2002). Apart from fruit texture and taste, the most important quality trait is good appearance, which requires adequate post-harvest handling to avoid damaging the fruits. The main causes of such damage are black putridity caused by the fungus Ceratocystis spp. and white rot caused by the fungus Monilia spp. as well as mechanical damage and deformation (Godoy et al. 2007).

\section{Processing}

Processing of peach palm fruits has not yet spread widely, since diverse peach palm products have not been developed and promoted, and linkages between farmers and the food industry are virtually non-existent. Nonetheless, processed peach palm products are considered to hold considerable potential for national and international markets (Leakey 1999; Godoy et al. 2007). To realize this potential the food industry needs to identify desirable traits for potential food products (Leakey 1999). Some evidence suggests that red and less oily types are preferred for canned fruits and jelly production. Deformed and damaged fruits could be processed for flour production (Godoy et al. 2007). In Cali, Colombia, peach palm has achieved a conspicuous presence in large supermarkets and shopping malls, where women sell fresh fruit and more limited quantities of processed fruit are available on the shelves. Processed fruits are either vaccum packed or canned in brine or processed into marmalede. In the southern Colombian city of Popayán, very tasty peach palm chips are sold in small packets. Though just beginning to enter mainstream markets, chips are believed to have large potential.

Delgado et al. (1988) and Mora-Kopper et al. (1997) have studied food uses of peach palm flour. Tracy (1987) determined that peach palm flour at $10 \%$ could serve as a substitute for wheat in bread baking, yielding dough of excellent baking quality. Peach palm has also been studied for possible use in producing pasta from a mixture of $15 \%$ peach palm flour and $85 \%$ wheat. In cooking tests for spaghetti and twist noodles, adding peach palm flour to the pasta did not significantly alter its quality and texture (De Oliveira et al. 2006). Indigenous people of the Amazon use peach palm fruits to produce caicuma or cachiri, a fermented alcoholic beverage similar to beer (Andrade et al. 2003; Grenand 1996). Peach palm flour, which is abundant in the Brazilian Amazon, was found to be a valuable alternative source of vitamin A for people in Manaus, Brazil (Yuyama and Cozzolino 1996). Vitamin A in peach palm is highly bioavailable (Yuyama et al. 1991). Peach palm processing offers a good option for making use of fruit types that consumers do not prefer for direct consumption and for thus alleviating problems of overproduction. 
Nutritional value of peach palm

\section{Nutritional composition}

Peach palm can be consumed in large quantities, serving mainly as an energy source that is poor in proteins and minerals (Leterme et al. 2005). Its nutritional composition varies depending on the ecotype and geographic region. The fruit's oil and starch content are particularly variable (Table 4). The most important mineral elements in peach palm are potassium, selenium and chromium (Yuyama et al. 2003). One kilogram of peach palm protein contains, on average, 16-49 $\mathrm{g}$ of lysine, 8-13 $\mathrm{g}$ of methionine, $19 \mathrm{~g}$ of cysteine, 27-39 $\mathrm{g}$ of threonine and 4.5-7 $\mathrm{g}$ of tryptophan (Leterme et al. 2005). The fruits contain all essential and non-essential amino acids, with tryptophan and methionine showing the lowest concentrations (Yuyama et al. 2003). Andrade et al. (1998) analyzed volatile constituents of peach palm, finding that limonene constitutes the major component $(52.9 \%)$. Texture analysis showed a firmness loss of 2.0, on average. Dry matter was strongly correlated with texture both in raw and cooked peach palm. It is also correlated with fat and protein content (Giraldo et al. 2009; Rodriguez et al. 2009), though starch content was found to be inversely correlated with oil (Leterme et al. 2005; Giraldo et al. 2009).

Carrera (1999) studied the chemical and physical properties of starches isolated from six Peruvian peach palm phenotypes. Starch was found to represent the highest share of dry matter composition, suggesting that peach palm is an excellent starch source for the Amazon region. The properties of peach palm starch require further study to determine possible industrial uses. Jane et al. (1992) isolated starch from peach palm originating in different parts of Costa Rica and studied its pasting, gelling and thermal properties. They found that amylose concentration range from 8 to $19 \%$ and phosphorus content from 0.049 to $0.054 \%$. Branch chain lengths of amylopectin determined by peak fraction showed polymerization degrees of 18 and 30 for short and long branches, respectively. The authors attributed variations in physical properties mainly to differences in amylose content and amylopectin structure (Jane et al. 1992).

According to Leterme et al. (2005) the content of truly digestible protein in peach palm is $51 \mathrm{~g} \mathrm{~kg}^{-1}$ dry matter with $3.691 \mathrm{kcal} \mathrm{kg}^{-1}$ dry matter of digestible energy. Average values for the digestibility of dry matter, energy, starch and protein are 91, 87, 96 and $95 \%$, respectively. Varieties differed significantly only for starch. Quesada et al. (2011) reported a glycemic index of $35 \mathrm{mg} \mathrm{dl}^{-1}$ in peach palm mesocarp, which is low compared to white bread. Foods with low glycemic index values are considered beneficial for patients with diabetes and coronary diseases, as released sugars are absorbed more slowly.

\section{Lipids}

Peach palm oil contains omega-3 (linolenic acid), omega-6 (linoleic acid) and omega-9 (oleic acid) fatty acids. Oil content has been shown to increase as fruits mature, but with high variability between bunches and harvest seasons (Arkcoll and Aguiar 1984). Monounsaturated oleic acids predominated (except one outlier from French Guyana), and palmitic acid was found to be the most abundant saturated fatty acid. Among the essential fatty acids, linoleic acid was the most common (Table 5). Saturated fatty acids predominate in the seed, with very high content of lauric and myristic acids (Zumbado and Murillo 1984). Clement and Arkcoll (1991) have evaluated potential breeding strategies for converting peach palm into an oil crop. This is especially important given the deficiency of omega-3 fatty acids in industrialized country diets, which contribute to the so-called 


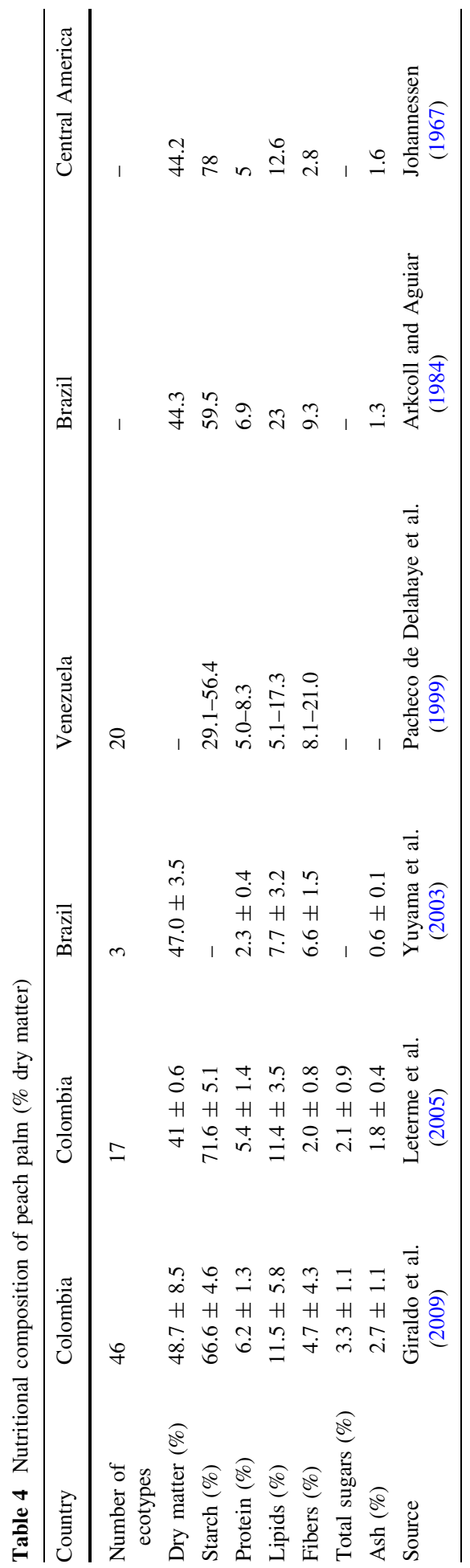


"diseases of civilization", including cardiovascular disease, cancer, and inflammatory and autoimmune diseases (Simopoulos 2004). There is strong evidence that increasing dietary omega-3 and other long-chain polyunsaturated fatty acids may ameliorate such diseases (Ruxton et al. 2004; Gogus and Smith 2010).

\section{Vitamin E (sterols)}

Natural vitamin E occurs in eight different forms, with $\alpha$-tocopherol and $\gamma$-tocotrienol accounting for most of it in palm oil. Natural tocopherol, particularly $\alpha$-tocopherol, is superior to synthetic forms as a radical chain-breaking antioxidant. The presence of this natural vitamin $\mathrm{E}$ in palm oil ensures a longer shelf-life for palm-based food products. By acting as an antioxidant, vitamin E plays an important role in the stabilization of oils and fats (Al-Saqer et al. 2004). Gas chromatographic analysis of peach palm sterols revealed the existence of several $\delta$-5-sterols (i.e., cholesterol, campesterol, stigmastérol, $\beta$-sitosterol and $\delta$-5-avenastérol). A HPLC study of tocopherols and tocotrienols showed that alpha tocopherol predominates in the banding patterns (Lubrano et al. 1994). Bereau et al. (2003) reported low levels of antioxidant (vitamin E) levels, more similar to those of olive oil than palm oil.

\section{Carotenoids}

Carotenoids are a group of phytochemicals, which are responsible for different colors of foods (Edge et al. 1997), including the orange to red color of the peach palm fruit mesocarp. Carotenoids are known to possess high anti-oxidant potential, which is considered to play an important role in preventing human diseases (Rao and Rao 2007). Epidemiological studies strongly suggest that consumption of carotenoid-rich foods reduces the incidence of diseases such as cancers and cardiovascular diseases (Ziegler 1989). Diets that are rich in fruits and vegetables, particularly with cooked products containing oil, offer the health benefits of carotenoids (Perera and Yen 2007). Latin America has a wide variety of carotenogenic foods that are notable for their diversity and high levels of carotenoids, but chemical assays commonly underestimate the antioxidant activity of food carotenoids (Rodriguez-Amaya 1999, 2010). In this respect peach palm can be considered a promising food crop, as its mesocarp is generally rich in $\beta$-carotene, though the level varies greatly (Arkcoll and Aguiar 1984). Furtado et al. (2004) studied carotenoid concentration in vegetables and fruits that are commonly consumed in Costa Rica, reporting values for peach palm of 4.2, 59.1, 93.2, 20.5 and $63.7 \mu \mathrm{g} \mathrm{g}^{-1}$ for $\alpha-$ carotene, trans- $\beta$-carotene, cis- $\beta$-carotene, trans-lycopene and cis-lycopene, respectively. Jatunov et al. (2010), using spectrophotometry, found significant differences in the total carotenoid content of six varieties of B. gasipaes from Costa Rica. Blanco and Munoz (1992) found similar carotenoid contents in raw and cooked peach palm and determined nutrient retention after cooking to be greater than $85 \%$. De Rosso and Mercadante (2007) quantified carotenoids in six Amazonian fruit species commonly sold in the city of Manaus (i.e., Mauritia Vinifera, Mammea Americana, Geoffrola striata, B. gasipaes, Physalis angulata and Astrocaryum aculeatum). All were found to be good sources of provitamin A, and total carotenoid content ranged from 38 to $514 \mu \mathrm{g} \mathrm{g}^{-1}$, with peach palm presenting an intermediate value of $198 \mu \mathrm{g} \mathrm{g}^{-1}$. Rojas-Garbanzo et al. (2011) identified nine carotenoids in raw peach palm fruit from Costa Rica, the most predominant being all-trans $\beta$-carotene. 


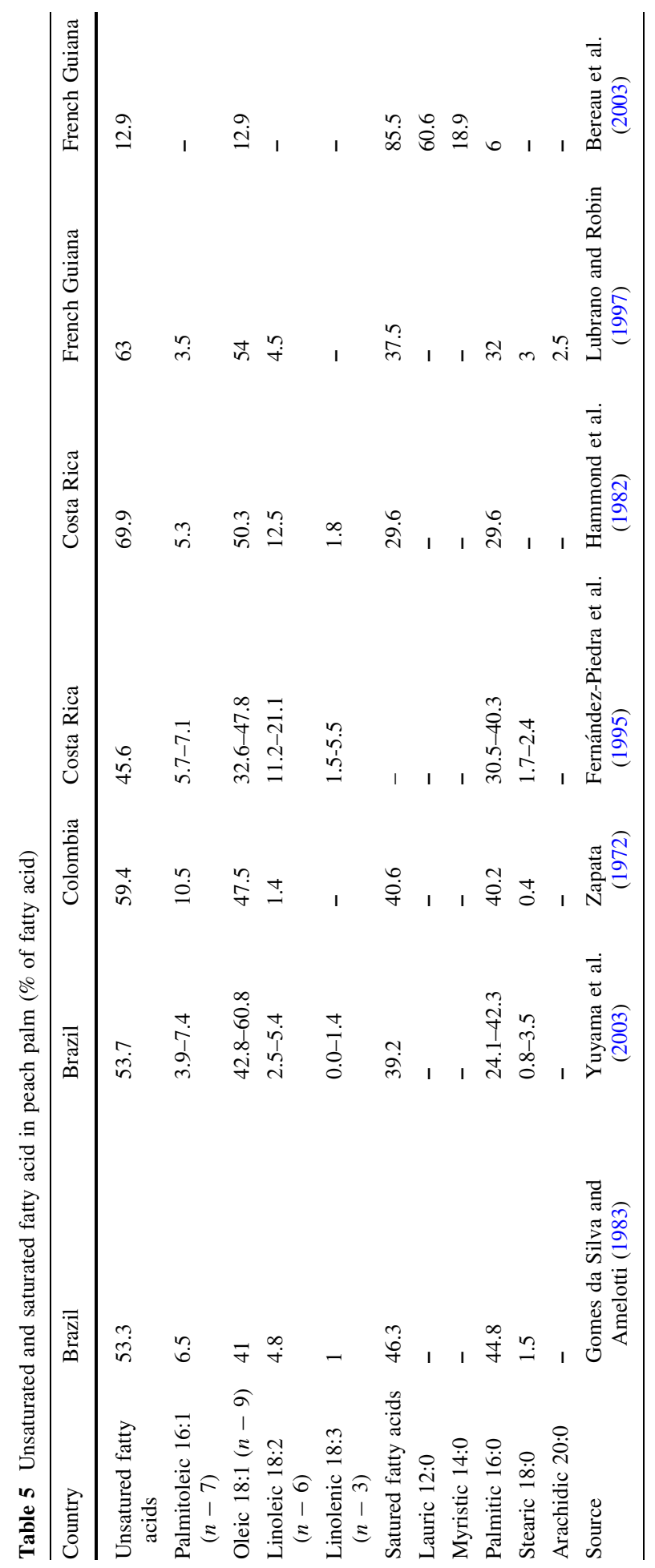


Peach palm as animal feed

An estimated 40-50\% of peach palm production never reaches the market and is either fed to farm animals or wasted (Clement et al. 2004). With low fiber and high starch content peach palm fruits are considered to hold considerable potential as an energetic ingredient of animal feed, especially as a substitute for maize (Clement 1990). Starchy fruit varieties with low oil content are usually preferred for animal nutrition (Leakey 1999). Caloric values obtained as true metabolizable energy (TME) indicate that peach palm has higher energy content than maize and also that it is unnecessary to separate the seeds from the fruits in animal feeds (Zumbado and Murillo 1984), which represent another option for adding value to secondquality fruits. Ensiling is considered the most attractive option for processing peach palm fruits into animal feed, especially as this process avoids drying and heat treatments to deactivate the trypsin inhibitor. However, since peach palm is low in protein, protein-rich additions are required when the fruit is used as silage for cattle (Clay and Clement 1993). Benavides (1994) found a mixture of $60 \%$ peach palm and $40 \%$ coral bean (Erythrina berteroana) to be best for ensiling. Coral bean foliage offered a protein-rich alternative, and the silage was high in digestibility. Another advantage of ensiled peach palm fruits is that the manure of livestock to which it is fed can easily be returned as fertilizer to the plants, thus closing the nutrient cycle in the production system (Clay and Clement 1993).

Peach palm fruits can be also processed into a concentrate for poultry, pigs and fish and into multi-nutritional blocks for cows, goats and sheep (Argüello 1999). In certain moist tropical regions, where cereals do not yield well without considerable amounts of inputs, evidence suggests that producing animal feed based on peach palm could be cheaper than importing maize (Clay and Clement 1993). Data from the Brazilian Cerrados suggest that peach palm fruits could meet all or part of the caloric requirements of poultry, on a par with millet or sorghum. The fruits are estimated to provide $3,500 \mathrm{kcal} \mathrm{kg}^{-1}$ of metabolizable energy (Teixeira et al. 1996). Data from Brazil further indicate that Bactris heartof-palm production can be combined usefully with livestock keeping, as cattle can be fed with spineless peach palm leaves, which are estimated to accumulate at a rate of $15 \mathrm{t} \mathrm{ha}^{-1}$ year $^{-1}$ (Smith et al. 1995; Teixeira et al. 1996). Baldizan et al. (2010) has shown that peach palm oil might efficiently provide up to $25 \%$ of the dietary energy in broiler diets. Birds fed on the peach palm oil had a significantly higher LDLC/HDLC ratio than with other dietary treatments (i.e., palm oil, maize oil and beef tallow).

\section{Other uses}

There is a small niche market for peach palm wood, especially dark brown wood with yellow stripes, which is preferred for furniture, parquet, and handicrafts (Clement 2006). One important characteristic of peach palm wood is its hardness, which makes it useful for construction (Patiño 1989).

\section{Conclusions}

Both cultivated and wild peach palm populations are genetically diverse and likely contain a wide range of potentially useful traits. Ex situ collections conserve this diversity but are costly to maintain. Screening peach palm diversity for biochemical and morphological traits of commercial and nutritional value would provide a basis for rationalizing collections and enhance the use of peach palm genetic resources. Elite material could be used 
either directly for production or in breeding to develop improved peach palm varieties. Materials showing traits of interest could be conserved on farm through the establishment of local clonal or seed orchards. At the same time, better propagation techniques should be developed to ensure wide distribution of elite peach palm clones.

Detailed vulnerability analyses should be conducted to provide a basis for targeting research that responds to the needs of people who depend on peach palm value chains. Pests and diseases also require further study in the main production areas. Likewise, efficient and safe harvesting methods should be developed and disseminated as well as improved transportation and storage methods that do not damage the fruits. New technological packages must be easy to disseminate and well suited to farmers' needs.

With respect to fruit processing centralized cooking facilities should be established to encourage the creation of small enterprises and reduce the drudgery of women street vendors. Associations of producers and street vendors need strengthening in terms of organizational, accounting and business skills. Participatory evaluation of business plans with key actors in the value chain would also be helpful. More alliances with public and private laboratories and enterprises are needed, especially in the pharmaceutical and cosmetic sectors, to realize the potential for processing novel products from peach palm.

Though consumers express clear preferences for certain fruit types, the market continues to supply a plethora of fruits differing in color, size, oil content and texture. Peach palm is produced by numerous smallholder households each with a few palms. The market for their fruits is large enough to accommodate a wide range of genetic diversity, so it is unlikely that a few varieties meeting a narrow range of consumer preferences will ever dominate the market, as is the case with crops like mango, avocado and banana.

This review suggests that improved cultivation, processing and marketing of peach palm have significant potential for enhancing food security and incomes in both rural and urban settings. Sustainable management of peach palm agroforestry systems could also generate valuable ecosystem services, such as carbon sequestration, nutrient cycling and biodiversity conservation. To realize these potential gains requires participatory research that directly involves stakeholders from the beginning and addresses multiples challenges in the different stages of production, processing and marketing.

Acknowledgments The Amazon Initiative, INIA-Spain, EMBRAPA, USAID and CIRAD provided funding for this study. Furthermore MvZ thanks the CGIAR Research Program on Forests, Trees and Agroforestry for financial support. We are grateful to CATIE and INIA-Peru for providing access to the peach palm materials from their genebank collections. We further thank Andreas Ebert, Carlos Astorga, William Solano, Sixto Imán, Manuel Sigueñas and Jesus Salcedo for their support with fruit collection and logistics. Lucia Chávez, Andres Giraldo and Andres Escobar conducted nutritional analyses, and Mauricio Quintero, David Quintero and Alexander Pereira provided valuable support in the development of the "bajachonta tool". We are grateful to all the farmers from the Colombian Pacific coast who gave us insight into their peach palm production systems. Special thanks also to Xavier Scheldeman for his valuable ideas and comments and to Nathan Russell for editing the manuscript.

Open Access This article is distributed under the terms of the Creative Commons Attribution License which permits any use, distribution, and reproduction in any medium, provided the original author(s) and the source are credited.

\section{References}

Acevedo JC, Zuluaga JJ, Martínez A (1996) El cultivo de chontaduro (Bactris gasipaes H.B.K.). Corporación Colombiana de Investigación Agropecuaria (CORPOICA), Florencia 
Adin A, Weber JC, Sotelo Montes C, Vidaurre H, Vosman B, Smulders MJM (2004) Genetic differentiation and trade among populations of peach palm (Bactris gasipaes Kunth) in the Peruvian Amazon: implications for genetic resource management. Theor Appl Genet 108:1564-1573

Almeyda N, Martin FW (1980) Cultivation of neglected tropical fruits with promise. Part 8. The pejibaye. United States Department of Agriculture (USDA), New Orleans

Al-Saqer JM, Sidhu JS, Al-Hooti SN, Al-Amiri HA, Al-Othman A, Al-Haji L, Ahmed N, Mansour IB, Minal J (2004) Developing functional foods using red palm olein. IV. Tocopherols and tocotrienols. Food Chem 85(4):579-583

Alves-Pereira A, Clement CR, Picanco-Rodrigues D (2012) Genetic divergence among populations and accessions of the spineless peach palm from Pampa Hermosa landrace used in the heart-of-palm agribusiness in Brazil. Genet Mol Biol 35:474-479

Alvim R, Virgens AC, Araujo AC (1992) La agricultura como ciencia para ganar dinero con la tierra: Recuperación y remuneración anticipadas del capital en el establecimiento de cultivos perennes arbóreos en Bahía, Brasil. In: Montagnini F (ed) Sistemas agroforestales: Principios y aplicaciones en los trópicos. Organización para Estudios Tropicales (OET), San José, pp 395-412

Andrade EHD, Santos AS, Zoghbi MDG, Maia JGS (1998) Volatile constituents of fruits of Astrocarium vulgare Mart. and Bactris gasipaes HBK (Arecaceae). Flavour Frag J 13(3):151-153

Andrade JS, Pantoja L, Maeda RN (2003) Improvement on beverage volume yield and on process of alcoholic beverage production from pejibaye (Bactris gasipaes Kunth). Ciencia Tecnol Alime 23: $34-38$

Araújo CM, Rodrigues DP, Filho SA, Clement CR (2010) Genetic variability in the peach palm genebank with RAPD markers. Crop Breed Appl Biot 10:211-217

Ares A, Falcao N, Yuyama K, Yost RS, Clement CR (2003) Response to fertilization and nutrient deficiency diagnostic in peach palm in Central Amazonia. Nutr Cycl Agroecosyst 6:221-232

Argüello H (1999) Cultivos y tecnologías para la reconversión económica en la Amazonia Colombiana. Universidad Nacional de Colombia, Instituto Amazónico de Investigaciones, Bogotá

Arkcoll DB, Aguiar JPL (1984) Peach palm (Bactris gasipaes HBK), a new source of vegetable oil from the wet tropics. J Sci Food Agric 35(5):520-526

Arkoll DB (1982) Considerações sobre a produção de alimentos por arvores e florestas. Acta Amazonica 12(2):247-249

Baldizan G, Oviedo M, Michelangeli C, Vargas RE (2010) Effects of peach palm oil on performance, serum lipoproteins and haemostasis in broilers. Br Poult Sci 51(6):784-790

Benavides JE (1994) Árboles y arbustos forrajeros en América Central. Informe técnico no. 236, Centro Agronómico Tropical de Investigación y Enseñanza (CATIE), Turrialba

Bereau D, Benjelloun-Mlayah B, Banoub J, Bravo R (2003) FA and unsaponifiable composition of five Amazonian palm kernel oils. J Am Oil Chem Soc 80(1):49-53

Bernal R, Torres C, García N, Isaza C, Navarro J, Vallejo MI, Galeano G, Balslev H (2011) Palm management in South America. Bot Rev 77:607-646

Blanco A, Munoz L (1992) Pejibaye (Bactris gasipaes) total carotenoid content and biological bioavailability as a source of vitamin-A. Arch Latinoam Nutr 42(2):146-154

Botero Botero L, Atehortua L (1999) Propagación in vitro de la palma de chontaduro (Bactria gasipaes H.B.K) por embriogénesis somática. Memorias del VI Seminario Nacional y II Internacional de Recursos Vegetales Promisorios, Universidad del Chocó, Quibdó, pp 95-100

Brondizio E (2004) From staple to fashion food: shifting cycles and shifting opportunities in the development of the acai fruit palm economy in the Amazonian estuary. In: Zarin DJ, Alavalapati JrR, Putz EF, Schmink M (eds) Working forest in the neotropics. Columbia University Press, New York, pp 339-365

Carrera L (1999) Isolation and characterisation of pejibaye starch. J Appl Bot 73(3-4):122-127

Clay JW, Clement CR (1993) Selected species and strategies to enhance income generation from Amazonian forests. Food and Agriculture Organization of the United Nations (FAO), Rome

Clement CR (1986) The pejibaye palm (Bactris gasipaes H.B.K.) as an agroforestry component. Agrofor Syst 4:205-219

Clement CR (1989) The potential use of the pejibaye palm in agroforestry systems. Agrofor Syst 7:201-212

Clement CR (1990) Pejibaye. In: Nagy S, Shaw PE, Wardowski WF (eds) Fruits of tropical and subtropical origin: composition, properties and uses. Florida Science Source Inc., Lake Alfred, pp 302-321

Clement CR (2006) Pupunha: De alimento básico a bocadillo. In: Lopez C, Shanley P, Cronkleton MC (eds) Riquezas del bosque: Frutas, remedios y artesanías en América Latina. CIFOR, Santa Cruz, pp 20-24

Clement CR, Arkcoll DB (1991) The pejibaye (Bactris gasipaes HKB palmae) as an oil crop: potential and breeding strategy. Oleagineux 46(7):293-299 
Clement CR, Santos LA (2002) Pupunha no mercado de Manaus: Preferências de consumidores e suas implicações. Rev Bras Frutic 24(3):778-779

Clement CR, Urpi J (1987) Pejibaye palm (Bactris gasipaes, Arecaceae): multiuse potential for the lowland humid tropics. Econ Bot 41(2):302-311

Clement CR, Yuyama K, Chávez Flores WB (2001) Recursos genéticos de pupunha (genetic resources of pejibaye). In: Sousa NR, Souza AGC (eds) Recursos fitogenéticos na Amazônia Ocidental: conservação, pesquisa e utilização. Embrapa Amazônia Ocidental, Manaus, pp 143-187

Clement CR, Weber JC, van Leeuwen J, Astorga Domian C, Cole DM, Arevalo Lopez LA, Argüello H (2004) Why extensive research and development did not promote use of peach palm fruit in Latin America. Agrofor Syst 61:195-206

Clement CR, Santos RP, Desmouliere SJM, Ferreira EJL, Farias Neto JT (2009) Ecological adaptation of wild peach palm, its in situ conservation and deforestation-mediated extinction in southern Brazilian Amazonia. PLoS One 4:e4564

Clement CR, de Cristo-Araújo M, Coppens d'Eeckenbrugge G, Alves Pereira A, Picanço D (2010) Origin and domestication of native Amazonian crops. Diversity 2:73-106

Cole DM, White TL, Nair PKR (2007) Maintaining genetic resources of peach palm (Bactris gasipaes Kunth): the role of seed migration and swidden-fallow management in northeastern Peru. Genet Resour Crop Evol 54:189-204

Constantino LM, Caicedo HC, Torres A (2003) Manejo integrado del barrenador del fruto de chontaduro (Palmelampius heinrrichi O'Brien \& Kovarik) con pequeños productores del Municipio de Guapi, Cauca. Fundación Levante en marcha, Auspicio PRONATTA, Cali

Coomes OT, Burt GJ (1997) Indigenous market-oriented agroforestry: dissecting local diversity in western Amazonia. Agrofor Syst 37:27-44

Cordero J, Boshier DH, Barrance A, Beer J, Chamberlain J, Detlefsen G, Finegan B, Galloway G, Gómez M, Gordon J, Hands M, Hellin J, Hughes CA, Ibrahim M, Kass D, Leakey RB, Mesén F, Montero M, Rivas C, Somarriba E, Stewart J, Pennington T (2003) Arboles de Centroamérica: Un manual para extensionistas. Centro Agronómico Tropical de Investigación y Enseñanza (CATIE), Turrialba

Cornelius JP, Clement CR, Weber JC, Sotelo-Montes C, van Leeuwen J, Ugarte-Guerra LJ, Ricse-Tembladera A, Arevalo-López L (2006) The trade-off between genetic gain and conservation in a participatory improvement programme: the case of peach palm (Bactris gasipaes Kunth). Forests Trees Livelihoods 16:17-34

Cornelius JP, Weber JC, Sotelo-Montes C, Ugarte-Guerra LJ (2010) Phenotypic correlations and site effects in a Peruvian landrace of peach palm (Bactris gasipaes Kunth). Euphytica 173:173-183

Couvreur TLP, Bilotte N, Risterucci A-M, Lara C, Vigouroux Y, Ludeña B, Pham J-L, Pintaud J-C (2006) Close genetic proximity between cultivated and wild Bactris gasipaes Kunth revealed by microsatellite markers in Western Ecuador. Genet Resour Crop Evol 53:1361-1373

Couvreur TLP, Hahn WJ, de Granville J-J, Pahm J-L, Ludeña B, Pintaud J-C (2007) Phylogenetic relationships of the cultivated Neotropical palm Bactris gasipaes (Arecaceae) with its wild relatives inferred from chloroplast and nuclear DNA polymorphisms. Syst Bot 32(3):519-530

Da Silva JBF, Clement CR (2005) Wild pejibaye (Bactris gasipaes Kunth var. chichagui) in Southeastern Amazonia. Acta Bot Bras 19(2):281-284

De Oliveira MKS, Martinez-Flores HE, de Andrade JS, Garnica-Romo MG, Chang YK (2006) Use of pejibaye flour (Bactris gasipaes Kunth) in the production of food pastas. Int J Food Sci Tech 41(8): 933-937

De Rosso VV, Mercadante AZ (2007) Identification and quantification of carotenoids, by HPLC-PDA-MS/ MS, from Amazonian fruits. J Agric Food Chem 55(13):5062-5072

Delgado CL, Cioccia A, Brito O (1988) Utilization of the fruit of pijiguao (Guilielma-gasipaes) as human food. 1 Background, nutritional and energetic potential and characteristics of plant and fruit. Acta Cient Venez 39(1):90-95

Domínguez JA (1990) Leguminosas de cobertura de cacao Theobroma cacao L. y pejibaye Bactris gasipaes H.B.K. Master thesis, Centro Agronómico Tropical de Investigación y Enseñanza (CATIE), Turrialba

Edge R, McGarvey DJ, Truscott TG (1997) The carotenoids as anti-oxidants: a review. J Photochem Photobiol 41(3):189-200

FAO (1983) Reunión de Consulta sobre Palmeras poco Utilizadas de América Tropical (Turrialba, Costa Rica). Organización de las Naciones Unidas para la Agricultura y la Alimentación (FAO), Rome

Fernández-Piedra M, Blanco-Metzler A, Mora-Urpí J (1995) Fatty acids contained in 4 pejibaye palm species, Bactris gasipaes (Palmae). Rev Biol Trop 43:61-66

Ferreira E (1999) The phylogeny of pupunha (Bactris gasipaes Kunth, Palmae) and allied species. In: Henderson A, Borchsenius F (eds) Evolution, Variation and Classification of palms, vol 83. Memoirs of the New York Botanical Garden, New York, pp 225-236 
Furtado J, Siles X, Campos H (2004) Carotenoid concentrations in vegetables and fruits common to the Costa Rican diet. Int J Food Sci Nutr 55(2):101-113

GBIF (2011) Global Biodiversity Information Facility. http://data.gbif.org/species/. Accessed 20 May 2012

Gepts P (2004) Crop domestication as a long-term selection experiment. In: Janick J (ed) Plant breeding reviews, vol 24., Part 2, Long-term selection: crops, animals, and bacteriaWiley, New York, pp 1-44

Giraldo A, Dufour D, Rivera AF, Sánchez T, Scheldeman X, González A (2009) Diversidad del chontaduro (Bactris gasipaes) consumido en Colombia. In: CD-Proceedings CIBIA VII, Integrando la ingeniería de alimentos con el bienestar, Bogota, Colombia, September 2009. Revista de la Asociación Colombiana de Ciencia y Tecnología de Alimentos N 18, ISSN 2027-2030

Godoy SP, Pencue L, Ruiz A, Montilla DC (2007) Clasificación automática de chontaduro (Bactris gasipaes) para su aplicación en conserva, mermelada y harinas. Facultad de Ciencias Agropecuarias 5(2):137-146

Gogus U, Smith C (2010) n-3 Omega fatty acids: a review of current knowledge. Int J Food Sci Technol 45(3):417-436

Gomes da Silva W, Amelotti G (1983) Chemical composition of the fatty fraction of Guilielma speciosa Mart. fruit. Riv Ital Sostanze Gr 60(12):767-770

Grenand F (1996) Cachiri: l'art de la bière de manioc chez les Wayapi de Guyane. In: Bataille-Benguigui MC, Cousin F (eds) Cuisines: reflets des sociétés. Ed. Sépia, MNHN, Paris, pp 325-345

Haag D (1997) Root distribution patterns in a polycultural system with local tree crops on an acid upland soil in Central Amazonia. Master thesis, University of Bayreuth

Hammond EG, Pan WP, Mora-Urpi J (1982) Fatty acid composition and glyceride structure of the mesocarp and kernel oils of the pejibaye palm (Bactris gasipaes H.B.K.). Rev Biol Trop 30(1):91-93

Hamrick JL, Godt MJW (1996) Effects of life history traits on genetic diversity in plant species. Philos T R Soc B 351:1291-1298

Henderson A (2000) Bactris (Palmae). Flora Neotropica 79:1-181

Hernández-Ugalde JA, Mora-Urpí J, Rocha-Nuñez O (2008) Diversidad genética y relaciones de parentesco de las poblaciones silvestres y cultivadas de pejibaye (Bactris gasipaes, Palmae), utilizando marcadores microsatelites. Rev Biol Trop 56:217-245

Hernández-Ugalde JA, Mora-Urpí J, Rocha-Nuñez O (2011) Genetic relationships among wild and cultivated populations of peach palm (Bactris gasipaes Kunth, Palmae): evidence for multiple independent domestication events. Genet Resour Crop Evol 58:571-583

Hollingsworth PM, Dawson IK, Goodall-Copestake WP, Richardson JE, Weber JC, Sotelo Montes C, Pennington RT (2005) Do farmers reduce genetic diversity when they domesticate tropical trees? A case study from Amazonia. Mol Ecol 14(2):497-501

IIAP (1995) Informe anual 1995. Instituto de Investigaciones de la Amazonia Peruana (IIAP), Yurimaguas

INCIVA (1982) Distancias adecuadas y número de retoños por cepa en el cultivo semicomercial del chontaduro de la Costa del Pacífico. Instituto Vallecaucano de Investigaciones Científicas (INCIVA), Cali

INIAA (1990) Estación experimental agraria San Ramón: Memoria anual 1990. Instituto Nacional de Investigación Agraria y Agroindustrial (INIAA), Yurimaguas

Jane JL, Shen L, Aguilar F (1992) Characterization of pejibaye starch. Cereal Chem 69(1):96-100

Jatunov S, Quesada S, Diaz C, Murillo E (2010) Carotenoid composition and antioxidant activity of the raw and boiled fruit mesocarp of six varieties of Bactris gasipaes. Arch Latinoam Nutr 60(1):99-104

Johannessen C (1967) Pejibaye palm: physical and chemical analysis of the fruit. Econ Bot 21(4):371-378

Labarta RA, Weber JC (1998) Valorización económica de bienes tangibles de cinco especies arbóreas agroforestales en la cuenca amazónica peruana. Revista Forestal Centroamericana 23:12-21

Leakey RRB (1999) Potential for novel food products from agroforestry trees: a review. Food Chem 6:1-14

Lehman Danzinger H (1993) Caídas de frutos de Chontaduro (Bactris gasipaes H.B.K) en el Pacífico Central de Colombia: Identificación y Control de los Insectos Responsables. Proyecto Costa Pacífico Fase II. Corporación Autónoma Regional del Valle del Cauca (C.V.C), Comunidad Económica Europea (C. E. E.), Buenaventura

Lehmann J, Da Silva Jr JP, Schroth G, Gebauer G, Da Silva LF (2000a) Nitrogen use in mixed tree crop plantations with a legume cover crop. Plant Soil 225:63-72

Lehmann J, Da Silva Jr JP, Trujillo L, Uguen J (2000b) Legume cover crops and nutrient cycling in tropical fruit tree production. Acta Hortic 531:65-72

Lehmann J, Muraoka T, Zech W (2001) Root activity patterns in an Amazonian agroforest with fruit trees determined by 32P, 33P and 15N applications. Agrofor Syst 52:185-197

Leterme P, Garcia MF, Londoño AM, Rojas MG, Buldgen A, Souffrant WB (2005) Chemical composition and nutritive value of peach palm (Bactris gasipaes Kunth) in rats. J Sci Food Agr 85(9):1505-1512 
Lieberei R, Gasparotto L, Preisinger H, Schroth G, Reisdorff C (2000) Characteristics of Sustainable polyculture production systems on terra firme. In: Lieberei R, Bianchi H-K, Boehm V, Reisdorff C (eds) Neotropical Ecosystems. Proceedings of the German-Brazilian Workshop, Hamburg, 2000. GKSS, Geesthacht, pp 653-660

Lopez G, Lozano N (2005) Estudio sobre el mercado del pijuayo. World Agroforestry Center (ICRAF), Lima

Lubrano C, Robin JR (1997) Major compounds study in fruit pulp oils of six Guiana Palms species. Acta Bot Gallica 144(4):495-499

Lubrano C, Jr Robin, Khaiat A (1994) Fatty-acid, sterol and tocopherol composition of oil from the fruit mesocarp of 6 palm species in French-Guiana. Oleagineux 49(2):59-65

MADR (2009) Anuario estadístico de frutas y hortalizas 2004-2008. Ministerio de Agricultura y Desarrollo Rural, Republica de Colombia, Bogota

McGrath DA, Comerford NB, Duryea ML (2000) Litter dynamics and monthly fluctuations in soil phosphorous availability in an Amazonian agroforest. Forest Ecol Manag 131:167-181

Medina MA, Mena A, Prohens J, Nuez F (2007) Survey of cultivated and wild edible plant species used in the Department of Chocó. PGR Newslett 150:54-63

Mejía MA (1978) Incidencia de una explotación intensiva de la palma de chontaduro en la situación socioeconómica de la población del Litoral Pacífico Vallecaucano. Boletín divulgativo no. 3, Secretaría de Agricultura y Fomento, Cali

Mora-Kopper S, Mora-Urpi JE, Mata Segreda JF (1997) Lipolytic activity in meals of pejibaye palm fruit (Bactris gasipaes, Palmae). Rev Biol Trop 45:597-599

Mora-Urpí J (1999) Origen y domesticación. In: Mora-Urpí J, Gainza EJ (eds) Palmito de Pejibaye (Bactris gasipaes Kunth): Su Cultivo e Industrialización. Editorial de la Universidad de Costa Rica, San José, pp $17-24$

Mora-Urpí J, Weber JC, Clement CR (1997) Peach palm. Bactris gasipaes Kunth. Promoting the conservation and use of underutilized and neglected crops. 20. Institute of Plant Genetics and Crop Plant Research, Gatersleben/IPGRI, Rome

Morcote-Rios G, Bernal R (2001) Remains of palms (Palmae) at archaeological sites in the New World: a review. Bot Rev 67:309-350

O'Brien C, Kovarik P (2000) A new genus and new species of weevil infesting fruits of the palm Bactris gasipaes H.B.K. (Coleoptera: Curculionidae). Coleopterits Bull 54(4):459-465

Pacheco de Delahaye E, Alvarado A, Salas R, Trujillo A (1999) The chemical composition and digestibility of the protein of twenty ecotypes of Pijiguao of the Venezuelan Amazon. Arch Latinoam Nutr 49(4):384-387

Pardo Locarno LC, Constantino LM, Agudelo R, Alarcon A, Caicedo V (2005) Observaciones sobre el gualapán (Coleoptera: Chrysomelidae: Hispinae) y otras limitantes entomológicas en cultivos de chontaduro en el bajo Anchicayá. Acta Agronómica (Colombia) 54(2):25-31

Patiño VM (1989) Comportamiento de plantas nativas colombianas bajo cultivo: Situación actual de cultivo del chontaduro. Revista de la Academia Colombiana de Ciencias Exactas, Físicas y Naturales 17(65):259-264

Patiño VM (1995) Datos etnobotánicos adicionales sobre el cachipay o pijibay (Bactris gasipaes Kunth), arecaceae, y especies afines en América intertropical. Revista de la Academia Colombiana de Ciencias Exactas, Físicas y Naturales 19(75):661-671

Patiño VM (2000) Historia y dispersión de los frutales nativos del Neotrópico. International Center for Tropical Agriculture (CIAT), Cali

Peña EA, Reyes R, Bastidas S (2002) Barrenador del fruto del chontaduro en la costa pacífica Colombiana. Boletín Divulgativo No. 16. Corporación Colombiana de Investigación agropecuaria (CORPOICA), Tumaco

Perera CO, Yen GM (2007) Functional properties of carotenoids in human health. Int J Food Prop 10(2):201-230

Pérez JM, Davey CB (1986) Requerimiento nutricional de pijuayo. Estación experimental San Ramón: Memoria anual 1986. Instituto Nacional de Investigación y Promoción Agropecuaria (INIPA), Yurimaguas, pp 267-271

Pérez F, Loayza J (1989) Estudio de rendimiento de pijuayo en Pucallpa. Instituto de Investigación de la Amazonia Peruana (IIAPE), Pucallpa

Postma TM, Verheij EWM (1994) Growth and yield of Bactris gasipaes and pourouma-cecropiaefolia in swidden fields of Amazon Indians Colombia. Sci Hortic Amsterdam 57(1-2):73-88

Quesada S, Azofeifa G, Jatunov S, Jiménez G, Navarro L, Gómez G (2011) Carotenoids composition, antioxidant activity and glycemic index of two varieties of Bactris gasipaes. Emir J Food Agric 23(6):482-489 
Quintero D (2008) De la palma al paladar: Características de la cadena productiva del chontaduro (Bactris gasipaes) en Colombia. International Center for Tropical Agriculture (CIAT), Cali

Rao AV, Rao LG (2007) Carotenoids and human health. Pharmacol Res 55(3):207-216

Reis VM (2009) Relações Genéticas entre Raças e Populações da Coleção Nuclear de Pupunha (Bactris gasipaes Kunth) Avaliadas com Microssatélites. Master thesis, Universidade Federal do Amazonas

Rivera AF (2009) Análisis fisicoquímicos y funcionales del chontaduro (Bactris gasipaes) en Colombia y la cuenca amazónica. Master thesis, Universidad del Cauca

Rodrigues DP, Filho SA, Clement CR (2004) Molecular marker-mediated validation of morphologically defined landraces of Pejibaye (Bactris gasipaes) and their phylogenetic relationships. Genet Resour Crop Evol 51:871-882

Rodriguez F, Graefe S, Giraldo A, Dufour D, Gonzalez A (2009) Food security, income generation and natural resource management of Afro-Colombian communities from the Pacific region through Access to markets: the case of peach palm (Bactris gasipaes K.). In: Tielkes E (ed) Biophysical and socioeconomic frame conditions for the sustainable management of natural resources. Tropentag 2009: international research on food security, natural resource management and rural development, Hamburg. Book of abstracts, p 490

Rodriguez-Amaya DB (1999) Latin American food sources of carotenoids. Arch Latinoam Nutr 49(3):74-84

Rodriguez-Amaya DB (2010) Quantitative analysis, in vitro assessment of bioavailability and antioxidant activity of food carotenoids: a review. J Food Compos Anal 23(7):726-740

Rojas-Garbanzo C, Pérez AM, Bustos-Carmona J, Vaillant F (2011) Identification and quantification of carotenoids by HPLC-DAD during the process of peach palm (Bactris gasipaes H.B.K.) flour. Food Res Int 44(7):2377-2384

Ruxton CHS, Reed SC, Simpson MJA, Millington KJ (2004) The health benefits of omega-3 polyunsaturated fatty acids: a review of the evidence. J Hum Nutr Diet 17(5):449-459

Salamanca CR, Cano AC (2005) Efecto de las micorrizas y el sustrato en el crecimiento vegetativo y nutrición de cuatro especies frutales y una forestal en fase de vivero. Suelos Ecuatoriales 35(2):5-11

Santos RP, de Cristo-Araújo M, Picanço-Todrigues D, Filho SA, Clement CR (2011) Genetic variability and gene flow in hybrid and wild populations of peach palm accessed with rapd markers. Rev Bras Frutic 33(4):1200-1208

Scheldeman X, Kanashiro M, Porro R, Dantas Medeiros R (2006) Amazon Initiative workshop on conservation and use of Amazonian fruits, Boa Vista, Brasil, September 2006. Organized by IPGRI, EMBRAPA and the Amazon initiative. http://www.iamazonica.org.br/conteudo/publicacoes/apresent Workshop/InformeBoaVistaFinal.pdf

Schroth G, D'Angelo SA, Teixeira WG, Haag D, Lieberei R (2002a) Conversion of secondary forest into agroforestry and monoculture plantations in Amazonia: consequences for biomass, litter and soil carbon stocks after 7 years. Forest Ecol Manag 163:131-150

Schroth G, Elias MEA, Macedo JLV, Mota MSS, Lieberei R (2002b) Mineral nutrition of peach palm (Bactris gasipaes) in Amazonian agroforestry and recommendations for foliar analysis. Eur J Agron 17(2):81-92

Silva CC (2004) Análise molecular e validação de raças primitivas de pupunha (Bactris gasipaes) por meio de marcadores RAPD. Masters Thesis, Universidade Federal de São Carlos/Universidade Federal do Amazonas

Simopoulos AP (2004) Omega-6/omega-3 essential fatty acid ratio and chronic diseases. Food Rev Int 20(1):77-90

Smith N, Serrao EA, Alvim P, Falesi IC (1995) Amazonia: Resiliency and dynamism of the land and its people. UNU studies on critical environmental regions. United Nations University Press, Tokyo

Sousa NR, Rodrigues DP, Clement CR, Nagao EO, Astolfi-Filho S (2001) Discriminação de raças primitivas de pupunha (Bactris gasipaes) na Amazônia brasileira por meio de marcadores moleculares (RAPDS). Acta Amazonica 31:539-545

Species link (2011) http://www.splink.org.br//. Accessed 3 July 2012

Steinmacher DA, Clement CR, Guerra MP (2007) Somatic embryogenesis from immature peach palm inflorescence explants: towards development of an efficient protocol. Plant Cell Tissue Organ Cult $89: 15-22$

Steinmacher DA, Guerra MP, Saare-Surminski K, Lieberei R (2011) A temporary immersion system improves in vitro regeneration of peach palm through secondary somatic embryogenesis. Ann Bot London 108:1463-1475

Teixeira CP, Paiva JC, Fraga PA (1996) Potencial socio-econômico da cultura da pupunha como alternativa para os Cerrados. In: Pereira RC, Nasser LC (eds) Simpósio sobre o Cerrado. Biodiversidade e produção sustentável de alimentos e fibras nos Cerrados: Anais. Empresa Brasileira de Pesquisa 
Agropecuária (EMBRAPA), Centro de Pesquisa Agropecuária dos Cerrados (CPAC), Planaltina, pp 159-161

Tracy M (1987) Utilization of pejibaye (Bactris gasipaes HBK) meal in bread making. Arch Latinoam Nutr 37(1):122-131

UNODC (2010) Análisis multitemporal de cultivos de coca, período 2008-2009. United Nations Office on Drugs and Crime (UNODC), Bogotá

Van Leeuwen J, Lleras Pérez E, Clement CR (2005) Field genebanks may impede instead of promote crop development: lessons of failed genebanks of "promising” Brazilian palms. Agrociencia 9(1-2):61-66

Vargas V, Aubert R (1996) Evaluación de sistemas agroforestales con barreras vivas, para la formación de terrazas en suelos con pendiente en Pucallpa. Informe Anual 1995. Programa Nacional de Investigación en Agroforestería y Cultivos Tropicales, Estación Experimental Pucallpa, Instituto Nacional de Investigación Agraria (INIA), Pucallpa

Velasco A, Patiño VM, Baracaldo R (1980) El chontaduro (Bactris gasipaes H.B.K.) en Colombia. Centro Agronómico Tropical de Investigación y Enseñanza (CATIE), Turrialba

Vélez O, Germán A (1991) Los frutales amazónicos cultivados por las comunidades indígenas de la región del Medio Caquetá (amazonia colombiana). Colombia Amazónica 5(2):163-193

Weber JC, Sotelo Montes C, Vidaurre H, Dawson IK, Simons AJ (2001) Participatory domestication of agroforestry trees: an example from the Peruvian Amazon. Dev Pract 11(4):425-433

Weitzman ML (1998) The Noah's Ark Problem. Econometrica 66:1279-1298

Winogrond W (2004) Colombia alternative development project. Survey of Department of Cauca. Chemonics International Inc., Washington

Ydrogo HF (1994) Efecto de la inoculación de lombrices de tierra Pontoscolex corethrurus (Glossoscolecidae) en las micorrizas Vesículo arbusculares y en la etapa de crecimiento de arazá (Eugenia stipitata), achiote (Bixa orellana) y pijuayo (Bactris gasipaes) en suelos ultisoles de Yurimaguas. Master thesis, Universidad Nacional de San Martín

Yuyama LKO, Cozzolino SMF (1996) Effect of supplementation with peach palm as source of vitamin A: study with rats. Rev Saude Publica 30(1):61-66

Yuyama LKO, Favaro RMD, Yuyama K, Vannucchi H (1991) Bioavailability of vitamin-A from peach palm (Bactris gasipaes HBK) and from mango (Mangifera indica 1) in rats. Nutr Res 11(10): $1167-1175$

Yuyama LKO, Aguiar JPL, Yuyama K, Clement CR, Macedo SHM, Favaro DIT, Alfonso C, Vasconcellos MBA, Pimentel SA, Badolato ESG, Vannucchi H (2003) Chemical composition of the fruit mesocarp of three peach palm (Bactris gasipaes) populations grown in Central Amazonia Brazil. Int J Food Sci Nutr 54(1):49-56

Zambrana NYP, Byg A, Svenning J-C, Moraes M, Grandez C, Balslev H (2007) Diversity of palm uses in the western Amazon. Biodivers Conserv 16:2771-2787

Zapata A (1972) Pejibaye palm from the pacific coast of colombia (a detailed chemical analysis). Econ Bot 26(2):156-159

Ziegler RG (1989) A review of epidemiologic evidence that carotenoids reduce the risk of cancer. J Nutr 119(1):116-122

Zumbado ME, Murillo MG (1984) Composition and nutritive-value of pejibaye (Bactris gasipaes) in animal feeds. Rev Biol Trop 32(1):51-56 